
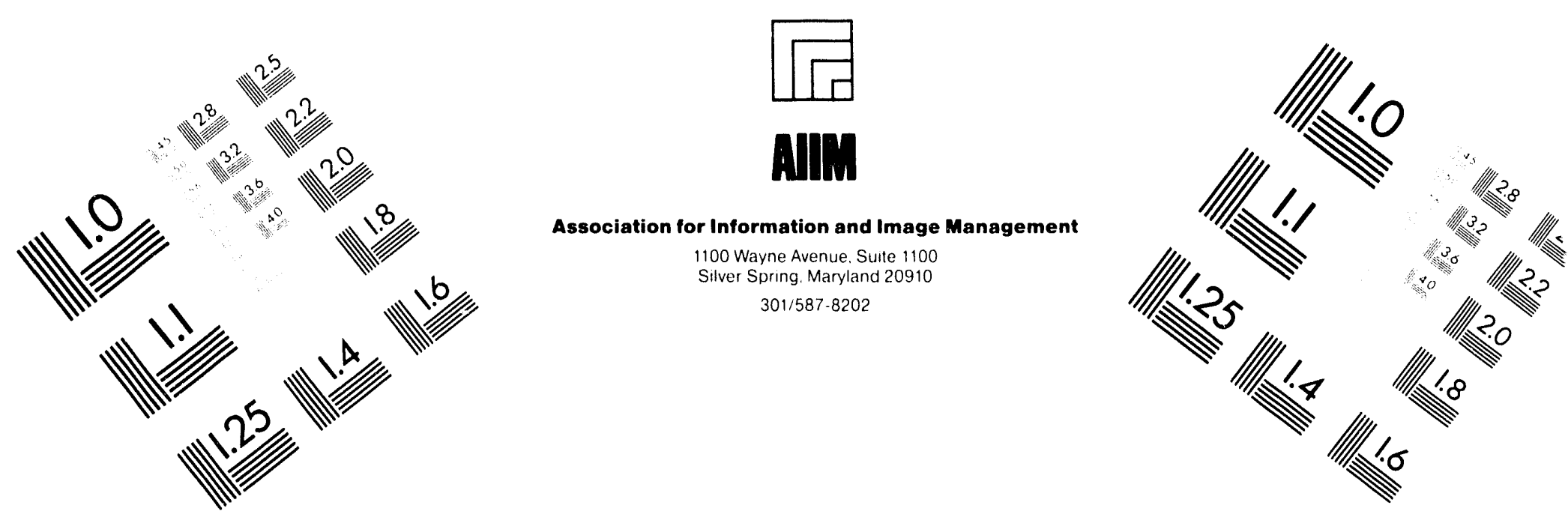

\title{
Centimeter
}

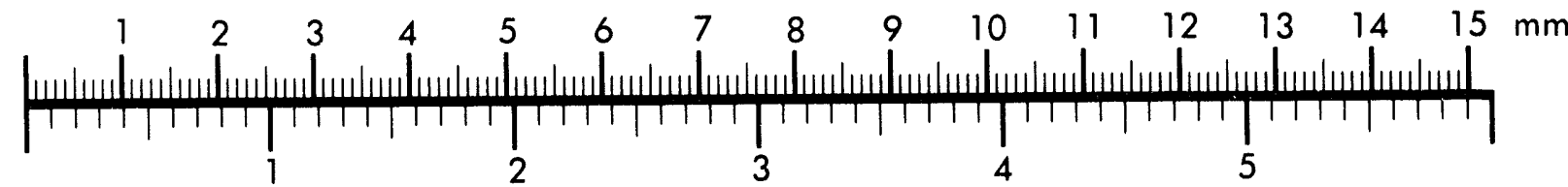

Inches
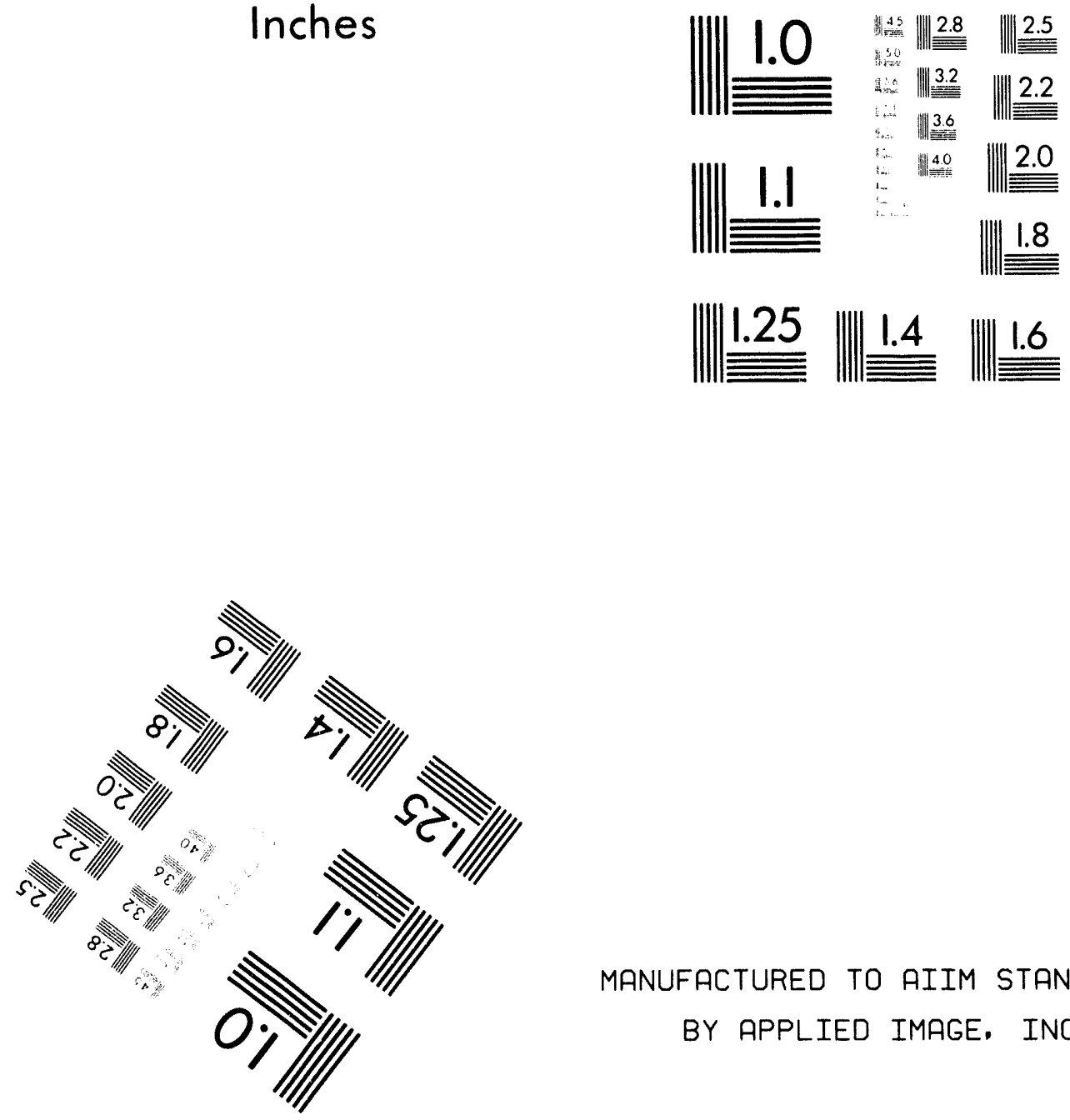

MANUFACTURED TO AIIM STANDARDS

BY APPLIED IMAGE, INC.

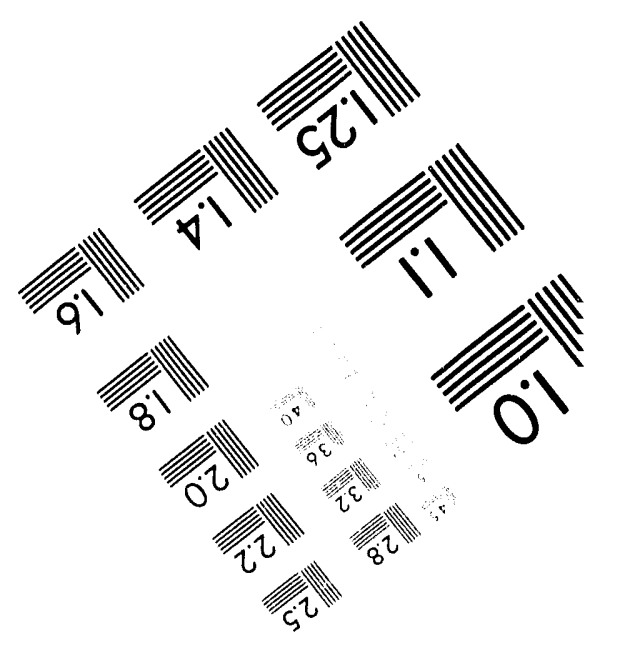



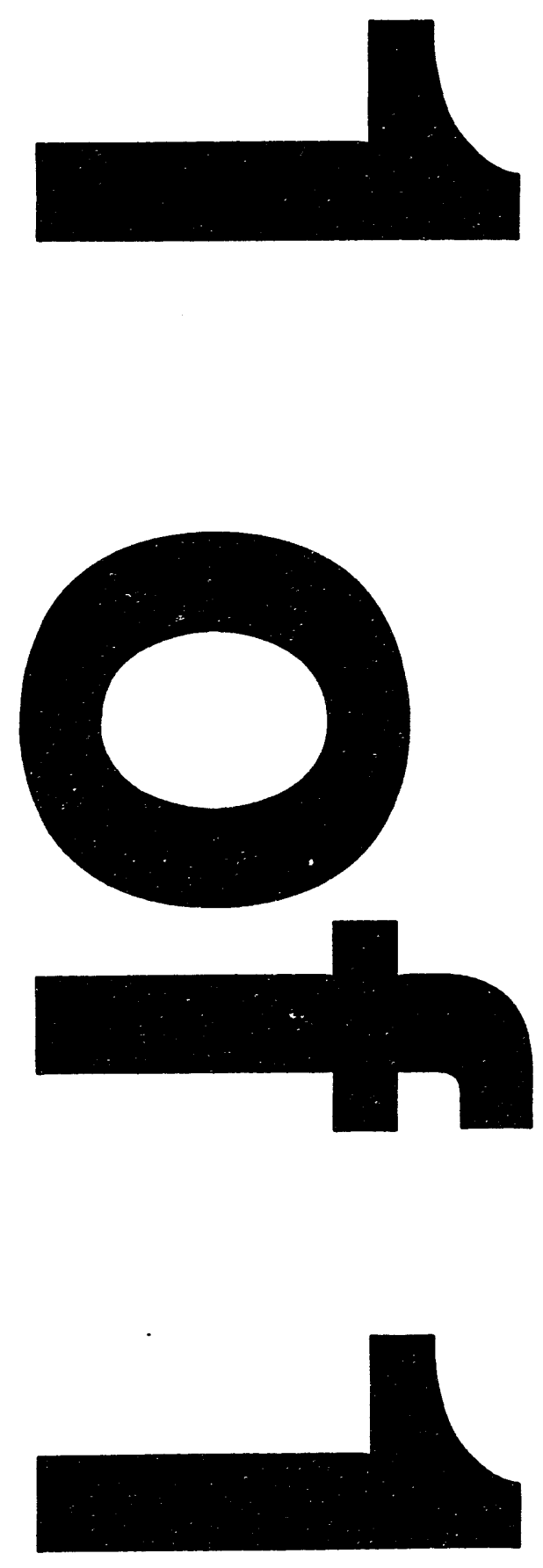


\section{Sources of Secondary Radionuclide Releases from Hanford Operations}

Hanford Environmental Dose Reconstruction Project

C. M. Heeb

S. P. Gydesen

May 1994

Letter Report prepared for the Technical Steering Panel and the Centers for Disease Control and Prevention under Contract 200-92-0503(CDC)/18620(BNW)

Battelle

Pacific Northwest Laboratories

Richland, Washington 99352 


\section{Preface}

In 1987, the U.S. Department of Energy (DOE) directed the Pacific Northwest Laboratory, which is operated by Battelle Memorial Institute, to conduct the Hanford Environmental Dose Reconstruction (HEDR) Project. The DOE directive to begin project work followed a 1986 recommendation by the Hanford Health Effects Review Panel (HHERP). The HHERP was formed to consider the potential health implications of past releases of radioactive materials from the Hanford Site near Richland, Washington.

Members of a Technical Steering Panel (TSP) were selected to direct the HEDR Project work. The TSP consists of experts in the various technical fields relevant to HEDR Project work and representatives from the states of Washington, Oregon, and Idaho; Native American tribes; and the public. The technical members on the panel were selected by the vice presidents for research at major universities in Washington and Oregon. The state representatives were selected by the respective state governments. The Native American tribes and public representatives were selected by the other panel members.

A December 1990 Memorandum of Understanding between the Secretaries of the DOE and the U.S. Department of Health and Human Services (DHHS) transferred responsibility for managing the dose reconstruction and exposure assessment studies to the DHHS. This transfer resulted in the current contract between Battelle, Pacific Northwest Laboratories (BNW) and the Centers for Disease Control and Prevention (CDC), an agency of the DHHS.

The purpose of the HEDR Project is to estimate the radiation dose that individuals could have received as a result of radionuclide emissions since 1944 from the Hanford Site. A major objective of the HEDR Project is to estimate doses to the thyroid of individuals who were exposed to iodine- 131 .

The HEDR Project work is conducted under several technical and administrative tasks, among which is the Source Term Task. Earlier source term reports contain estimates of radionuclide quantities released into the environment from primary sources: eight single-pass Hanford production reactors operated from 1944 to 1971 and four chemical separations plants operated from 1944 to 1972 (Heeb 1993, 1994a, 1994b).

This report is the final volume in the Source Term Task. In it, researchers evaluate possible secondary sources of radionuclide releases. These secondary sources include all DOE Hanford reactors not covered previously (with the exception of the $\mathrm{N}$ Reactor), ancillary facilities associated with the four primary chemical separations plants, an early tritium extraction operation, and the two criticality accidents that occurred at the Hanford Site. Releases studied were not found to have made significant impacts on doses to representative individuals. Therefore, data from this report are not included in pathway and dose estimation studies. This report fulfills Milestone 0306A. 


\section{Summary}

This report is the result of research for the Hanford Environmental Dose Reconstruction (HEDR) Project, a project conducted by Battelle, Pacific Northwest Laboratories. The report considers Hanford facilities and operations that had the potential to be secondary radionuclide release sources. In earlier reports conducted under the HEDR Project, researchers determined the origin, amount, and timing (source term) of the most significant (primary) radionuclide releases (Heeb 1993, 1994a, 1994b). Those reports cover releases to the air and the Columbia River from the eight single-pass reactors and four chemical separations plants.

Facilities that produced or processed radionuclides and were not covered in previous source term studies are examined in this report. The following facilities and operations are included:

- PUREX and REDOX - campaigns with non-standard feed material (materials other than fuel from single-pass reactors)

- C PLANT (Hot Semi-Works) - pilot plant and strontium recovery

- Z Plant - plutonium finishing

- $\mathrm{U}$ and $\mathrm{UO}_{3}$ Plants - uranium recovery

- 108 B Plant - tritium extraction

- 300 Area Plutonium Recycle Test Reactor (PRTR)

- 300 Area Low Power Test Reactors

- Criticality Accidents

- 400 Area Fast Flux Test Facility (FFTF).

All of the operations and facilities described in this report were found to be minor radionuclide contributors compared to the major Hanford sources discussed in three previous reports (Heeb 1993, 1994a, 1994b). The largest release discussed in this report is of tritium from the $108 \mathrm{~B}$ Plant operations. The reconstruction of tritium releases from 108 B, operated from 1949 to 1954 , provided a monthly scenario of releases to the atmosphere that totaled 200,000 curies. The largest monthly release of tritium from this plant was 43,000 curies in July 1954. This release would amount to a monthly dose of 0.30 mrem for the month of July 1954 . The results are summarized in Table S.1 
Table S.1. Summary of Facilities and Criticality Accidents

\begin{tabular}{|c|c|}
\hline Facility and/or Activity & Potential or Actual Release \\
\hline $\begin{array}{l}\text { PUREX and REDOX Non Single-Pass } \\
\text { Reprocessing }\end{array}$ & $\begin{array}{l}\text { The processed N, Thoria, Shippingport, and PRTR fuels had } \\
\text { radionuclide concentrations as high or higher than single-pass } \\
\text { fuel. Because releases were constrained by a long cooling time } \\
\text { and by release control equipment, the releases were less than } \\
\text { those for single-pass fuel processing. Annual environmental } \\
\text { reports do not report above-normal releases. }\end{array}$ \\
\hline C Plant (Hot Semi-Works) & $\begin{array}{l}\text { Low radionuclide throughput compared to full-scale plants } \\
\text { limited possible releases to fractions of full-scale B,T, REDOX } \\
\text { and PUREX releases. }\end{array}$ \\
\hline Z Plant - Plutonium Finishing & $\begin{array}{l}\text { Potential releases limited to plutonium and americ um. } \\
\text { Releases of plutonium smaller than from separation: plants. }\end{array}$ \\
\hline $\mathrm{U}$ and $\mathrm{UO}_{3}$ Plants - Uranium Recovery & $\begin{array}{l}\text { Potential releases limited to uranium. The } 1956-1966 \text { release is } \\
0.0192 \text { curies. }\end{array}$ \\
\hline 108 B Plant - Tritium Extraction & $\begin{array}{l}\text { Potential release limited to tritium. Estimated life of facility } \\
\text { (1949-1954) release is } 200,000 \pm 147,000 \text { curies. The dose for } \\
\text { this is estimated to be } 1.2 \text { mrem. Maximum monthly release } \\
\text { occurred in July } 1954 \text { of } 43,500 \pm 32,100 \text { curies. The monthly } \\
\text { dose from this release would be } 0.3 \text { mrem. }\end{array}$ \\
\hline $\begin{array}{l}300 \text { Area Plutonium Recycle Test } \\
\text { Reactor (PRTR) }\end{array}$ & $\begin{array}{l}\text { Potential releases primarily plutonium and fission products. } \\
\text { The } 70 \text {-megawatt reactor had a containment system and no } \\
\text { direct discharge of cooling water to river. Fuel failure on } \\
\text { September } 29,1965 \text { resulted in release of } 20 \text { curies of iodine- } \\
131 \text { and } 55 \text { curies of iodine-133 to the Columbia River at } \\
\text { Richland. }\end{array}$ \\
\hline 300 Area Low Power Test Reactors & $\begin{array}{l}\text { Potential releases negligible because of low power, minimal } \\
\text { burnup of fuel. No evidence of excursions or any accidinntal } \\
\text { releases. }\end{array}$ \\
\hline Criticality Accidents & $\begin{array}{l}\text { P-11 accident (November } 16,1951 \text { ) had potential for plutonium } \\
\text { and fission product release, but excursion limited to } 8 \times 10^{16} \\
\text { fissions ( } 0.08 \text { curie of iodine-131). Estimated } 1 \text { gram } 0 . \\
\text { plutonium released. } \\
\text { Recuplex accident (April } 7,1962 \text { ) had the potential for } \\
\text { plutonium and fission product release. Excursion laster } 37.5 \\
\text { hours and yielded } 8 \times 10^{17} \text { fissions ( } 0.8 \text { curie of iodine- } 31 \text { ). } \\
\text { Environmental effects "undetectable." }\end{array}$ \\
\hline 400 Area Fast Flux Test Facility (FFTF) & $\begin{array}{l}\text { 400-megawatt fast reactor extremely isolated from the } \\
\text { environment by design. Negligible releases to atmosphere. No } \\
\text { discharges to the Columbia River. }\end{array}$ \\
\hline
\end{tabular}




\section{Glossary}

200 Areas - designation for the two Hanford (200-East and 200-West) separations areas. Includes T Plant, B Plant, REDOX, and PUREX.

300 Areas - designation for areas containing research and development and fuel fabrication operations.

actinide, actinide element - any of a series of chemically similar, radioactive elements with atomic numbers ranging from 89 (actinium) through 103 (lawrencium).

activation product - radionuclide produced by neutron absorption by a radioactive or nonradioactive parent nuclide.

alpita particle - particle consisting of two protons and two neutrons.

alpha radiation - radiation emitted by alpha particles. This is the least penetrating type of radiation and can be stopped by a sheet of paper or the outer dead layer of skin.

B Plant - bismuth phosphate separations plant located in the 200-East Area.

B Reactor - first of eight Hanford single-pass production reactors.

batch - amount of irradiated fuel loaded into the dissolver at one time. "Charge" and "cut" are parts of a batch.

beta radiation - form of radiation emitted from a nucleus during radioactive decay; equivalent in mass and charge to an electron. Can be stopped by an inch of wood or a thin sheet of aluminum.

burnup - amount of energy generated by nuclear fuel; usually measured in megawatt days per ton of fuel (MWd/ton); also called "exposure."

C Plant - pilot plant for chemical separations (also known as Hot Semi-Works plant) located in 200-East Area.

C Reactor - one of eight single-pass Hanford production reactors.

campaign - in a separations plant, period of operations devoted to processing a given type of fuel; usually lasts several days or months.

charge - see "batch."

Ci - abbreviation for curie.

clad - container (usually aluminum or zirconium) for reactor fuel elements. 
composite sample - sample composed of small portions collected from several locations or from a single location over an extended time period.

computer code - computer implementation (program) of equations.

computer model - representation of a biological/physical process on a computer.

concentration - the amount of a specified substance (e.g., a radioactive element) in a unit amount of another substance (e.g., river water, milk).

confidence interval - statistical range with a specified probability that a given parameter lies within the range.

conceptual model - any representation of a biological or mechanical process.

critical - system neutron production equals neutron loss, resulting in a self-sustaining chain reaction.

criticality accident - unintended achievement of a sustained nuclear reaction; may imply an excursion, but not a release, of radioactive material.

critical mass - amount of fissionable material necessary to sustain a nuclear reaction.

curie - unit of radioactivity corresponding to $3.7 \times 10^{10}$ (37 billion) disintegrations per second (abbreviated $\mathbf{C i}$ ).

cut - part of a batch (single production run).

D Reactor - Hanford production reactor.

DR - Hanford production reactor.

days - working shift from 8 a.m. to 4 p.m.

deterministic - statistical method in which a single-point estimate is calculated (contrast with "stochastic"); also, a calculation using a single set of parameters to generate a single-value answer. For the HEDR Project, it is a mode of running a Monte Carlo code with the statistical sampling of distribution functions disabled.

dissolver - vessel used in the spent-fuel portion of the separations process.

DOE - Department of Energy

DOI - "do iodine," HEDR computer code used to simulate separations plant dissolver operations.

dose - radiation dose; often distinguished as absorbed dose, dose equivalent, or effective dose equivalent. 
dose decision levels - threshold below which research efforts to define doses are minimized. The dose decision levels for HEDR were determined by the TSP.

dose factor - factor that describes the amount of radiation dose received from a given intake of radioactivity.

excursion - increase in neutron flux level and reactor power. Unless the core is seriously damaged, an excursion is not accompanied by a release of radioactivity to the environment.

F Reactor - one of eight single-pass Hanford production reactors

fissile - radionuclide capable of undergoing fission: uranium-233, uranium-235, plutonium-239, plutonium-241 with neutrons of any energy.

fission - nuclear reaction in which the nucleus of an atom breaks up into two or more nuclei and releases energy (radiation).

fission yield - fractional amount of a given nuclide per fission event.

fuel element - aluminum-clad rod used to create plutonium and other radioactive materials in Hanford reactors. Generates heat in the reactor.

fuel element failure - rupture of a fuel element, leading to unusually high radioactive contamination of the cooling water.

gamma radiation - high energy, short wave-length electromagnetic radiation (a packet of energy) emitted from the nucleus; gamma rays are similar to $x$ rays, and require heavy shielding such as concrete or steel to be stopped.

Green Run - controlled release of radionuclides from T Plant in December 1949.

gross beta - total activity of beta-emitting radionuclides that could not be distinguished separately by instrumentation and did not include volatile beta-emitting radionuclides (see beta radiation).

H Reactor - one of eight single-pass Hanford production reactors.

half-life - time required for an initial number of radioactive atoms to be reduced to half that number by transformations.

heavy water - non-radioactive water composed of two deuterium (hydrogen-2) and one oxygen atom; used to slow down (moderate) neutrons and increase fission reactions in the reactor core.

HEDR Project - Hanford Environmental Dose Reconstruction Project.

holdup time - length of time a parent radionuclide spends in the reactor core; usually expressed in seconds. 
HTLTR - High Temperature Lattice Test Reactor

irradiation - exposure of an object to ionizing radiation.

isotope - one of two or more atoms having the same atomic number but different mass.

KE Reactor - one of eight single-pass Hanford production reactors.

KW Reactor - one of eight single-pass Hanford production reactors.

loading - number of tons of uranium contained in the reactor; also one of the distribution functions used to model uncertainty in the pile loading.

MTU - metric tons uranium (1000 kilograms; 2204.62 pounds); used only for separations plants.

mean - average value of a set of numbers.

median - middle value in a series of values arranged in order of size.

moderator - substance through which neutrons pass to slow them down (moderate them) and enhance fission reactions. At Hanford, graphite and deuterium were the most commonly used moderators.

modules - sections of a computer code.

Monte Carlo technique - method that represents the effect of uncertainty in one or more contributing parameters on the overall uncertainty by randomly sampling distribution functions that express parameter uncertainty.

mrad - millirad, one-thousandth of a rad.

mrem - millirem, one-thousandth of a rem.

natural uranium - naturally occurring uranium (0.711 percent uranium-235 in uranium-238).

N Reactor - only closed-system Hanford Reactor.

nCi - nanocurie, one billionth of a curie.

neutron - electrically neutral particle which, in conjunction with the proton, forms all atomic nuclei.

neutron flux - rate of neutron bombardment.

normal distribution - distribution function proportional to $e^{-u}$, where $u=(x-m)^{2} /\left(2 s^{2}\right)$ where $x$ is the statistical variable, $m$ is its mean, and $s$ is the standard deviation. 
off-gas line - dissolver vent that exhausted to the vent stack, which in turn exhausted to the atmosphere.

order of magnitude - order of 10 , term used to describe relative size. For example, two orders of magnitude is equal to two orders of 10 or 100 .

picocurie - one-trillionth of a curie.

proton - positively charged particle which, in conjunction with the neutron, forms all atomic nuclei.

process tube - aluminum tube that held the uranium fuel elements and cooling water in Hanford reactors.

production reactor - facility in which uranium or other fuel was irradiated with neutrons to produce radioactive materials. At Hanford, used primarily to produce plutonium for weapons; used also for research: B, C, D, DR, F, H, KE, KW, and N reactors. Synonymous with "reactor."

PRTR - Plutonium Recycle Test Reactor.

PUREX - Hanford chemical separations plant.

rad - radiation absorbed dose; unit of measurement.

radioactivity - spontaneous emission of radiation (alpha, beta, or gamma rays) by some isotopes as they decay into stable elements.

radionuclide - radioactive isotope of an element.

RATCHET - Regional Atmospheric Transport Code for Hanford Emission Tracking, computer code that models the air transport of radionuclides and provides daily integrated values of radionuclide surface contamination and concentrations in air.

realization - particular pass through a Monte Carlo simulation in which all stochastic parameters have been assigned a value; the simulation represents a possible reality.

recovery plant - site where uranium was recovered from the waste solvent used in separations plant operations (U Plant and $\mathrm{UO}_{3}$ Plant).

REDOX - Hanford chemical separations plant.

regression - statistical method that uses the algorithm of one or more independent variables for which the parameters have been adjusted to minimize difierences between actual values and estimated values.

release - escape of radioactive material into the environment. 
release factor - ratio of radionuclide amount released to the radionuclide amount processed.

rem - roentgen equivalent man, unit of measurement used to describe dose equivalence.

representative individuals - hypothetical individuals sharing similar characteristics significant to estimating dose.

retention time - length of time effluent water was held in a retention basin before discharge to the Columbia River; normally expressed in hours.

separations plant - facility where plutonium from irradiated reactor fuel was separated from other fuel-rod components and fission products (T Plant, B Plant, C Plant, REDOX, and PUREX).

sensitivity - determination of the parameters and pathways that contribute most to uncertainty in calculations.

single-pass reactors - production reactors on the Hanford Site that did not recirculate Columbia River water but instead discharged it through retention basins to the Columbia River: B, C, D, DR, F, H, $\mathrm{KE}, \mathrm{KW}$ reactors. Later designs used a closed system to recirculate water: $\mathrm{N}$ reactor. See production reactor.

source term - amount of radioactivity (curies) of a radionuclide released to the environment from a facility at a given time.

spent fuel - irradiated fuel discharged from a reactor.

stack - primary release point of exhaust air from a reactor or separations plant building.

stochastic - method of estimating possible values by using a range of possible input parameters to arrive at a corresponding range of possible results (contrast with "deterministic").

STRM - Source Term Release Model, computer code that provides estimates of iodine-131 releases that occurred between 1944 and 1949 from the separations plants to the atmosphere.

STRRM - Source Term River Release Model; computer code that provides estimates of monthly releases of radionuclides from Hanford reactors to the Columbia River.

supercritical - system neutron production is greater than neutron loss, causing increase in the thermal power of the reactor.

T Plant - Hanford chemical separations plant.

target elements - non-fuel elements targeted for radiation; do not generate fission heat in the reactor.

test reactors - used to test materials and processes for a variety of applications; used also for reactor physics measurements. 
thoria - thorium dioxide.

ton $-2,000$ pounds.

transmission factor - amount of radioactivity that remains after municipal water treatment.

tritium - isotope of hydrogen with one proton and two neutrons in the nucleus.

TSP - Hanford Environmental Dose Reconstruction Project Technical Steering Panel.

U PLANT - chemical plant designed to convert T and B plant uranium by-product to uranium nitrate hexahydrate solution (UNH).

UNH - uranium nitrate hexahydrate.

uncertainty - measure of the precision with which dose estimates can be made.

$\mathrm{UO}_{3}$ - uranium trioxide.

$\mathrm{UO}_{3}$ PLANT - chemical plant design to convert UNH solutions to $\mathrm{UO}_{3}$.

watts - unit of power.

WSU-CHARIMA - Washington State University modification of CHARIMA, computer code that models transport and dilution of radionuclides in the Columbia River.

Z PLANT - plutonium finishing plant complex at Hanford. 


\section{Contents}

Preface $\ldots \ldots \ldots \ldots \ldots \ldots \ldots \ldots \ldots \ldots \ldots \ldots \ldots \ldots \ldots \ldots$ ii

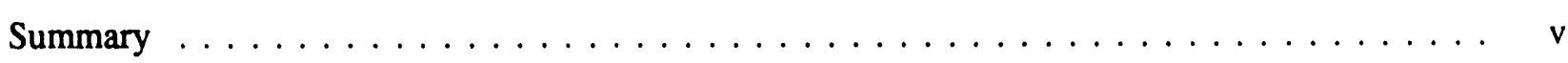

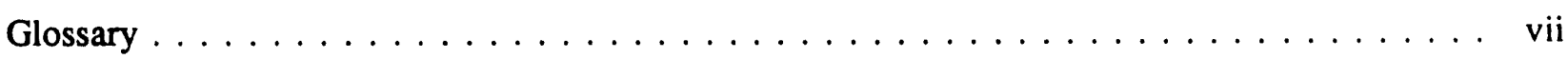

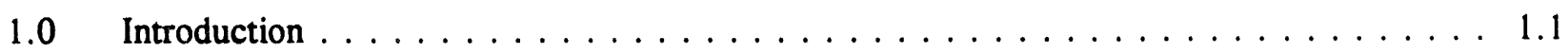

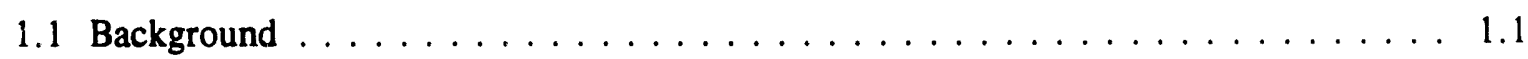

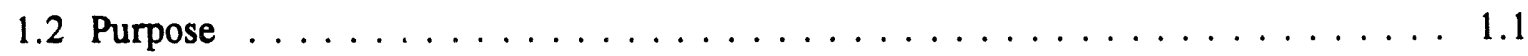

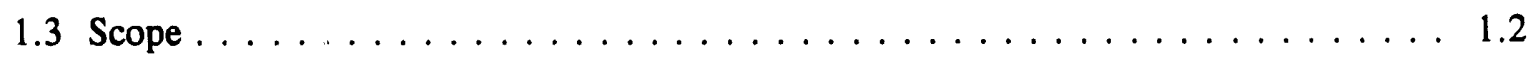

1.4 Technical Approach . . . . . . . . . . . . . . . . . . 1.2

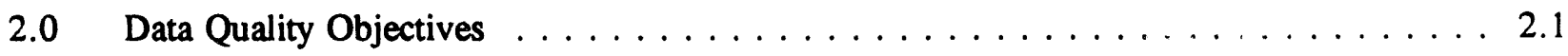

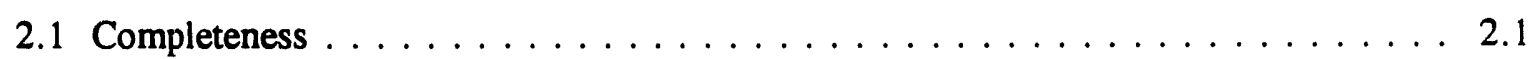

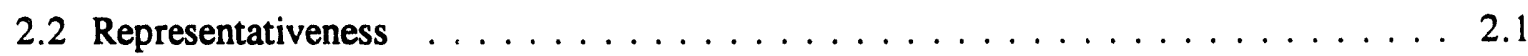

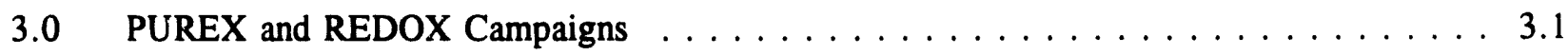

3.1 PUREX N-Reactor Fuel Processing Campaigns $\ldots \ldots \ldots \ldots \ldots \ldots \ldots$

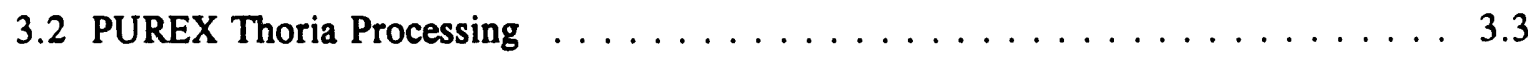

3.3 REDOX Campaigns . . . . . . . . . . . . . . . . . 3.5

4.0 C Plant (Hot Semi-Works) - Pilot Plant and Strontium Recovery . . . . . . . . . . . 4.1

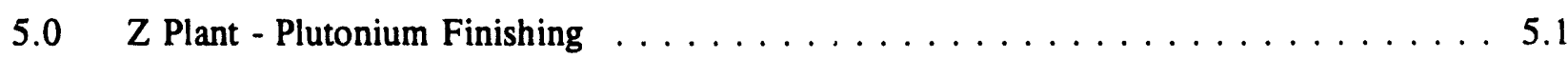

$6.0 \mathrm{U}$ and $\mathrm{UO}_{3}$ Plants - Uranium Recovery $\ldots \ldots \ldots \ldots \ldots \ldots$

$7.0 \quad 108$ B Plant - Tritium Extraction $\ldots \ldots \ldots \ldots \ldots \ldots \ldots \ldots \ldots \ldots$

8.0300 Area Plutonium Recycle Test Reactor $\ldots \ldots \ldots \ldots \ldots \ldots \ldots \ldots$

9.0300 Area Low Power Test Reactors and Critical Experiment Facilities . . . . . . . . . 9.1

9.1305 Hanford Test Pile $\ldots \ldots \ldots \ldots \ldots \ldots \ldots \ldots \ldots \ldots \ldots$ 
9.2 Physical Constants Test Reactor . . . . . . . . . . . . . . . 9.1

9.3 Plutonium Recycle Critical Facility $\ldots \ldots \ldots \ldots \ldots \ldots \ldots$

9.4 High Temperature Lattice Test Reactor $\ldots \ldots \ldots \ldots \ldots . \ldots . \ldots . \ldots . \ldots$

9.5 Training Research Isotopes General Atomics $\ldots \ldots \ldots \ldots \ldots . \ldots . \ldots . \ldots$

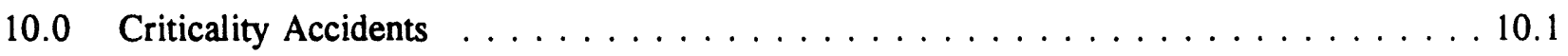

11.0400 Area Fast Flux Test Facility $\ldots \ldots \ldots \ldots \ldots \ldots \ldots \ldots \ldots \ldots \ldots$

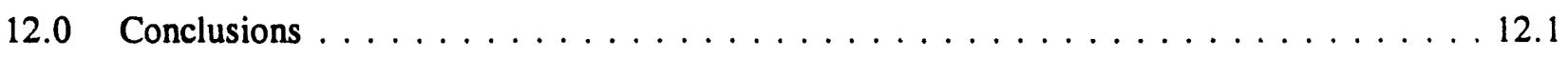

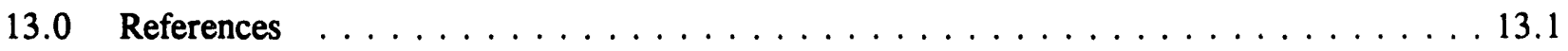

Appendix - Monthly Tritium Releases from 108 B $\ldots \ldots \ldots \ldots \ldots \ldots \ldots$ 


\section{Tables}

S.1 Summary of Facilities and Criticality Accidents $\ldots \ldots \ldots \ldots \ldots$ vi

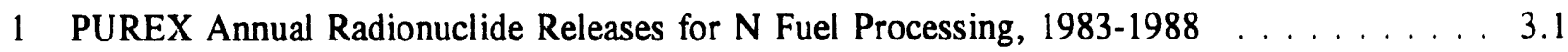

2 Amount of $\mathbf{N}$ Reactor Fuel Processed Annually at PUREX $\ldots \ldots \ldots \ldots .2$

3 N Reactor Fuel Amounts Processed at PUREX - Comparison of Charge Source Data with Data in Table $2 \ldots \ldots \ldots \ldots \ldots \ldots \ldots \ldots \ldots$

4 Monthly Thoria Fuel Discharged, Processed and in Storage Backlog . . . . . . . . . . 3.4

5 PRTR and Shippingport Processing at REDOX $\ldots \ldots \ldots \ldots \ldots \ldots$

6 Typical Releases from C Plant Stack in $1953 \ldots \ldots \ldots \ldots \ldots \ldots$

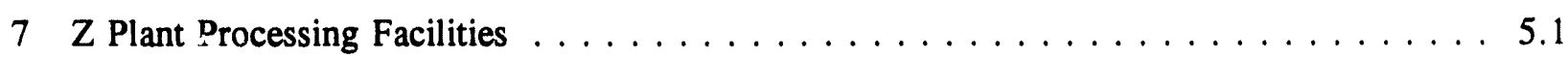

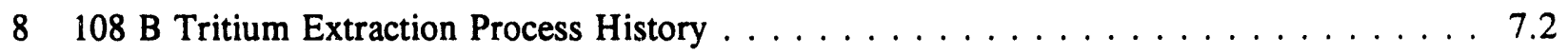

9108 B Tritium Release Factor Development $\ldots \ldots \ldots \ldots \ldots \ldots$

10 Discrete Tritium Release History from 108 B Plant $\ldots \ldots \ldots \ldots . \ldots$

11 Annual Amount of Tritium Processed and Released by 108 B Plant . . . . . . . . . . 7.5

12 Annual Curie Releases to Air from the Fast Flux Test Reactor $\ldots \ldots \ldots \ldots \ldots \ldots$

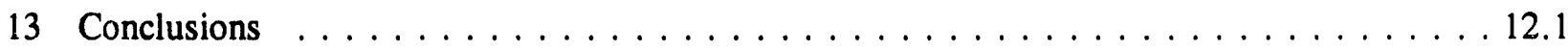

A.1 Monthly Tritium Releases from 108 B $\ldots \ldots \ldots \ldots \ldots \ldots \ldots \ldots$ 


\subsection{Introduction}

This report considers Hanford facilities and operations with the potential to be secondary radionuclide release sources. In earlier reports conducted under the Hanford Environmental Dose Reconstruction (HEDR) Project, researchers determined the origin, amount, and timing (source term) of primary radionuclide releases (Heeb 1993, 1994a, 1994b). Those reports cover releases to the air and the Columbia River from the eight single-pass reactors and air releases from the four chemical separation plants. This report considers other possible sources of significant releases from the Hanford Site.

\subsection{Background}

Plutonium was produced at the Hanford Site between 1944 and 1988 . The production process began with uranium fuel rods placed in a reactor and irradiated with neutrons. The nuclear reactions in uranium fuel transformed a small fraction of the uranium into plutonium. Separations plants segregated plutonium from uranium and other fuel element components in a series of chemical processing steps. Recovery plants removed uranium from the waste streams of separations plants. Throughout production processes, radionuclides created by fission reactions escaped to the environment through ventilation systems, discharged coolant water, or from solvent solutions. A small fraction of radionuclides in the irradiated uranium were released from the chemical separations plants. In eight of the nine production reactors, cooling water from the Columbia River was pumped through the reactor core and, after a brief retention time, was returned to the Columbia River. This reactor cooling water contained radionuclides produced in the reactor core.

These facilities and operations were sources of the largest radionuclide releases from the Hanford Site. The release amounts were estimated in detail in three previous HEDR reports (Heeb 1993, 1994a, 1994b). This study examines all the remaining Department of Energy (DOE) reactors at Hanford (except the $\mathrm{N}$ Reactor), the two criticality accidents, and separations and reprocessing plants.

\subsection{Purpose}

In order to reconstruct the radionuclide dose an individual received from the Hanford operations, the source, timing, and amount (source term) of radionuclides released must be reconstructed. This report includes estimated Hanford radioactive releases from sources other than production separations facilities and production reactors (Shipler 1993). It complements earlier source term studies (Heeb 1993, 1994a, 1994b), and was conducted to ensure that all secondary sources of radionuclide releases were considered. 


\subsection{Scope}

Facilities that produced radionuclides or processed products of fission reactions and were not covered in previous source term reports are included in this report. Certain facilities were excluded from the scope of this investigation (Shipler 1993) because, by the nature of their design, they could not have released significant amounts of radionuclides. N Reactor river releases were not included because the facility was a recirculating (closed system) reactor and did not discharge directly to the Columbia River.

The following facilities are described and any potentially significant releases from them are estimated:

- PUREX (1956-1972, 1983-1988) and REDOX (1952-1967) - campaigns with non-standard feed material (materials other than fuel from single-pass reactors)

- C PLANT (Hot Semi-Works) - pilot plant and strontium recovery

- Z Plant - plutonium finishing

- $\mathrm{U}$ and $\mathrm{UO}_{3}$ Plants - uranium recovery

- 108 B Plant - tritium extraction

- 300 Area Plutonium Recycle Test Reactor (PRTR)

- 300 Area Low Power Test Reactors

- Criticality Accidents

- 400 Area Fast Flux Test Facility (FFTF).

\subsection{Technical Approach}

The method of analysis was to examine each facility, give a brief description of its purpose and operations, and describe the types of material the facility processed as an indication of the radionuclides it had the potential to release. Where possible, specific radionuclides are estimated and values from the original documents are reported. In many facilities, small inventories of radionuclides made releases virtually impossible. Therefore, there was no system of regularly accounting for releases, and records were not kept except in the case of an unusual incident. 


\subsection{Data Quality Objectives}

The data quality objectives for estimating radionuclide releases to the air are defined in the integrated task plans (Shipler 1993).

\subsection{Completeness}

Information which covers the facilities and activities in this report was located by applying knowleage of activity, facility, time period and names of people associated with the facility or activity. Further references were found in the original documents which completed the coverage and filled obvious gaps in descriptions, time periods, and complete descriptions. Complete information was found for all of the targeted facilities and activities. Many of the facilities and activities had little potential for releases because of a lack of large radionuclide inventories or processing through-puts. Hence, no certifications of negligible releases were created.

\subsection{Representativeness}

The reference section of this document provides the required bibliography for the subject facilities and criticality accidents. 


\subsection{PUREX and REDOX Campaigns}

The PUREX and REDOX plants were used to separate plutonium from spent fuel rods. PUREX operated from 1956 to 1972, and again from 1983 to 1988. REDOX operated from 1952 to 1967. The most significant releases, which occurred when the plants processed fuel from single-pass reactors, are discussed in earlier HEDR reports (Heeb 1993, 1994a). The following sections discuss only processes and secondary releases not covered in previous reports.

\subsection{PUREX N-Reactor Fuel Processing Campaigns}

The PUREX plant completed processing of aluminum-clad single-pass reactor fuel in 1972 and was involved in processing approximately 3,900 tons of $\mathbf{N}$ Reactor fuel in the 1980s. The first step in the process, fuel dissolving, was modified to enable the dissolution of the zirconium-clad tube-intube $\mathbf{N}$ Reactor fuel. Operations were carried out with full airborne release control equipment and on fuel that, on average, had been stored for several years. The combination of these factors resulted in airborne releases that were much lower than those estimated for processing single-pass reactor fuel (Heeb 1994a).

The annual releases of the six most significant airborne radionuclides from 200 Area Chemical Separations Plants ${ }^{(a)}$ are shown in Table 1. (Blank entries indicate that no release was reported for that year.) The releases are all well below the annual releases reported by Heeb (1994a) for processing of single-pass reactor fuel in the 1944 to 1972 time period. Table 2.

The monthly amount of $\mathrm{N}$ Reactor fuel processed at PUREX per calendar year (CY) is shown in

Table 1. PUREX Annual Radionuclide Releases for N Fuel Processing (Ci), 1983-1988

\begin{tabular}{|l|l|l|l|l|l|l|l||}
\hline Year & ${ }^{90} \mathrm{Sr}$ & ${ }^{1{ }^{13} \mathrm{Ru}}$ & ${ }^{106} \mathrm{Ru}$ & ${ }^{131} \mathrm{I}$ & ${ }^{144} \mathrm{Ce}$ & ${ }^{239} \mathrm{Pu}$ & Reference \\
\hline \hline 1983 & .003 & 0.0 & 0.0 & 0.0 & 0.0 & .00062 & Price et al. 1984 \\
\hline 1984 & .023 & .0005 & 0.2 & 0.0 & 0.1 & .0074 & Price et al.1985 \\
\hline 1985 & .0085 & 0.52 & 0.62 & 0.2 & 0.1 & 0.01 & Price 1986 \\
\hline 1986 & .00021 & .02 & 0.4 & $<0.2$ & 0.0 & .003 & PNL 1987 \\
\hline 1987 & .0002 & $<.0002$ & .02 & $<.002$ & 0.0 & & $\begin{array}{l}\text { Jaquish and } \\
\text { Mitchell 1988 }\end{array}$ \\
\hline 1988 & .0001 & $<.0005$ & .18 & $<.0004$ & $<.0001$ & .0002 & $\begin{array}{l}\text { Jaquish and } \\
\text { Mitchell 1988 }\end{array}$ \\
\hline
\end{tabular}

(a) Letter (HEDR Froject Document No. 07930346), "Significant Nuclides Released to the Atmosphere," from J. E. Till (TSP Chair) to D. B. Shipler (BNW), June 29, 1993. 
Table 2. Amount of $\mathbf{N}$ Reactor Fuel Processed Annually at PUREX (MTU)

\begin{tabular}{|l|l|l|l|l|l|l||}
\hline & CY 1983 & CY 1984 & CY 1985 & CY 1986 & CY 1987 & CY 1988 \\
\hline Jan & & 102.7 & 145.7 & 49.26 & & 20.13 \\
\hline Feb & & 41.3 & 82 & 106.8 & 7.3 & 66.44 \\
\hline Mar & & 123.2 & 152.5 & 208.1 & 7.4 & 47.63 \\
\hline Apr & & 123.2 & 150.8 & 98.93 & 7.4 & 0 \\
\hline May & & 90.9 & 50.5 & 94.57 & 7.4 & 9.71 \\
\hline Jun & & 102.6 & 40.7 & 60.88 & 7.25 & 76 \\
\hline Jul & & 144.7 & 119.9 & 147.87 & 29.44 & 38.31 \\
\hline Aug & & 156.1 & 150.2 & 89.16 & 58.6 & 93.49 \\
\hline Sep & & 72.7 & 29.7 & & & 93.09 \\
\hline Oct & & 0 & 70.99 & & & 56.12 \\
\hline Nov & 39.3 & 31.2 & 120.46 & & & 58.89 \\
\hline Dec & 49.5 & 104.6 & 29.6 & & & 28.85 \\
\hline $\begin{array}{l}\text { Annual } \\
\text { Total }\end{array}$ & 88.8 & 1093.2 & 1142.82 & 855.57 & 124.79 & 588.66 \\
\hline $\begin{array}{l}\text { Total of } \\
\text { All Years }\end{array}$ & & & & & & 3894 \\
\hline
\end{tabular}

The annual totals derived from Table 2 were compared with PUREX charge source data that gave the weight of each fuel charge loaded into each of the three dissolvers operated during those years. Those results are shown in Table 3. 
Table 3. N Reactor Fuel Amounts Processed at PUREX (MTU) - Comparison of Charge Source Data with Data in Table 2.

\begin{tabular}{|c|c|c|}
\hline Calendar Year & Charge Data Totals & Table 2 Totals \\
\hline 1983 & 89 & 89 \\
\hline 1984 & 1092 & 1093 \\
\hline 1985 & 1143 & 1143 \\
\hline 1986 & 856 & 856 \\
\hline 1987 & 125 & 125 \\
\hline Totals & 3305 & 3306 \\
\hline
\end{tabular}

Totals from these independent sources agree closely, verifying that Table 2 is an accurate representation of the $\mathbf{N}$ Reactor fuel amounts processed. Copies of the detailed Table 3 charge data are available in HEDR Project records. ${ }^{(a)}$ Data in Table 2 are not used in any way to estimate releases but are included in this report to complete documentation of airborne releases from PUREX operations (Heeb 1994a).

\subsection{PUREX Thoria Processing}

Thoria processing produces uranium-233, fuel which is readily fissionable in the thermal neutron spectrum of the production reactors. Some of the bred uranium-233 was fissioned in-reactor, and the discharged thoria target contained fission products including strontium- 90 , ruthenium-103, ruthenium-106, iodine-131, cerium-144. The number of fissions, and hence the fission product concentrations, were far less than for normal uranium metal fuel elements in the Hanford single-pass production reactor. Consequently, fission product releases from processing thoria target elements were less than releases from processing normal fuel elements.

Starting in September (DeNeal 1970, p. 46), 1964 aluminum-clad thorium dioxide target elements were loaded into the production reactors. Uranium-233 is formed when thorium-232 absorbs a neution to produce thorium-233. Thorium-233 has a 22.2-minute half-life and decays by beta emission into protactinium-233, which has a 27 -day half-life and in turn decays by beta emission into uranium-233. Because protactinium-233 has a relatively long half-life, processing tended to wait until the protactinium-233 had a chance to decay. Fuel processed in this manner was stored for at least 200 days before it was treated to separate uranium-233 from the irradiated target.

Table 4 shows the monthly amounts of thoria fuel discharged and processed (Jungfleisch 1992) and the calculated cumulative backlog (stored product awaiting separations processing) of unprocessed

(a) Memorandum (HEDR Project Document No. 05940366), "PUREX N Fuel Reprocessing Data," from C. M. Heeb (BNW) to HEDR Project Records (BNW), May 18, 1994. 
thoria fuel. Fuel which had been stored longest was processed first. The 5.4 tons of unprocessed thoria fuel are probably due to roundoff error in the calculation. The discharge data had two significant figures to the right of the decimal, whereas the processed data contained only one significant figure to the right. Table 4 demonstrates that all of the thoria irradiated was processed to within 1-percent accuracy. Blanks in the table indicate periods when no fuel was processed.

Table 4. Monthly Thoria Fuel Discharged, Processed and in Storage Backlog (Tons)

\begin{tabular}{|c|c|c|c|c|c|c|c|c|c|}
\hline Yoar & Month & $\begin{array}{l}\text { Discharged } \\
\text { from } \\
\text { Reactor }\end{array}$ & $\begin{array}{l}\text { Processed } \\
\text { at PUREX }\end{array}$ & Backlog & Year & Month & $\begin{array}{c}\text { Discharged } \\
\text { from } \\
\text { Reactor }\end{array}$ & $\begin{array}{l}\text { Processed } \\
\text { at PUREX }\end{array}$ & Backlog \\
\hline 1965 & 4 & 0.67 & & 0.67 & 1969 & 1 & 24.90 & & 163.80 \\
\hline 1965 & 5 & 21.23 & & 21.90 & 1969 & 2 & 19.00 & & 182.80 \\
\hline 1965 & 6 & 25.61 & & 47.51 & 1969 & 3 & 8.70 & & 191.50 \\
\hline 1965 & 7 & 14.82 & & 62.33 & 1969 & 4 & & & 191.50 \\
\hline 1965 & 8 & 26.53 & & 88.86 & 1969 & 5 & 28.20 & & 219.70 \\
\hline 1965 & 9 & 25.89 & & 114.75 & 1969 & 6 & 34.20 & & 253.90 \\
\hline 1965 & 10 & 0.28 & & 115.03 & 1969 & 7 & 20.50 & & 274.40 \\
\hline 1965 & 11 & 0.33 & & 115.36 & 1969 & 8 & 0.10 & & 274.50 \\
\hline 1965 & 12 & 0.32 & & 115.68 & 1969 & 9 & 24.30 & & 298.80 \\
\hline 1966 & 1 & 0.74 & & 116.42 & 1969 & 10 & 23.00 & & 321.80 \\
\hline 1966 & 2 & 36.00 & & 152.42 & 1969 & 11 & 35.40 & & 357.20 \\
\hline 1966 & 3 & 51.59 & & 204.01 & 1969 & 12 & 6.40 & & 363.60 \\
\hline 1966 & 4 & 9.15 & & 213.16 & 1970 & 1 & 17.00 & & 380.60 \\
\hline 1966 & 5 & & & 213.16 & 1970 & 2 & 2.00 & & 382.60 \\
\hline 1966 & 6 & & & 213.16 & 1970 & 3 & 5.30 & & 387.90 \\
\hline 1966 & 7 & 0.10 & & 213.26 & 1970 & 4 & 0.40 & & 388.30 \\
\hline 1966 & 8 & 0.06 & 55.70 & 157.62 & 1970 & 5 & 0.30 & & 388.60 \\
\hline 1966 & 9 & & 130.90 & 26.72 & 1970 & 6 & & & 388.60 \\
\hline 1966 & 10 & 0.64 & 4.00 & 23.36 & 1970 & 7 & 5.40 & & 394.00 \\
\hline 1966 & 11 & 0.36 & & 23.72 & 1970 & 8 & 0.40 & 76.00 & 318.40 \\
\hline 1966 & 12 & 7.66 & & 31.38 & 1970 & 9 & & 97.00 & 221.40 \\
\hline 1967 & 1 & 6.32 & & 37.70 & 1970 & 10 & 0.80 & 73.30 & 148.90 \\
\hline 1967 & 2 & 27.20 & & 64.90 & 1970 & 11 & & 102.00 & 46.90 \\
\hline
\end{tabular}


Table 4. (contd)

\begin{tabular}{|c|c|c|c|c|c|c|c|c|c|}
\hline Year & Month & $\begin{array}{l}\text { Discharged } \\
\text { from } \\
\text { Reactor }\end{array}$ & $\begin{array}{c}\text { Processed } \\
\text { at } \\
\text { PUREX }\end{array}$ & Backlog & Year & Month & $\begin{array}{l}\text { Processod } \\
\text { at PUREXX }\end{array}$ & $\begin{array}{l}\text { Discharged } \\
\text { from } \\
\text { Reactor }\end{array}$ & Backlog \\
\hline 1967 & 3 & & & 64.90 & 1970 & 12 & & 41.50 & 5.40 \\
\hline 1967 & 4 & 0.10 & & 65.00 & 1971 & 1 & & & 5.40 \\
\hline 1967 & 5 & & & 65.00 & 1971 & 2 & & & 5.40 \\
\hline 1967 & 6 & 0.80 & & 65.80 & 1971 & 3 & & & 5.40 \\
\hline 1967 & 7 & 5.50 & & 71.30 & 1971 & $\overline{4}$ & & & 5.40 \\
\hline 1967 & 8 & 8.40 & & 79.70 & 1971 & 5 & & & 5.40 \\
\hline 1967 & 9 & & & 79.70 & 1971 & $\overline{6}$ & & & 5.40 \\
\hline 1967 & 10 & 5.00 & & 84.70 & 1971 & 7 & & & 5.40 \\
\hline 1967 & 11 & 0.20 & & 84.90 & 1971 & 8 & & & 5.40 \\
\hline 1967 & 12 & & & 84.90 & 1971 & 9 & & & 5.40 \\
\hline 1968 & 1 & & & 84.90 & 1971 & 10 & & & 5.40 \\
\hline 1968 & 2 & 4.90 & & 89.80 & 1971 & 11 & & & 5.40 \\
\hline 1968 & 3 & & & 89.80 & 1971 & 12 & & & 5.40 \\
\hline 1968 & $\overline{4}$ & & & 89.80 & & & & & \\
\hline 1968 & 5 & & & 89.80 & Sum & & 585.80 & 580.40 & \\
\hline 1968 & 6 & 4.40 & & 94.20 & & & & & \\
\hline 1968 & 7 & & & 94.20 & & & & & \\
\hline 1968 & 8 & 8.60 & & 102.80 & & & & & \\
\hline 1968 & 9 & 17.50 & & 120.30 & & & & & \\
\hline 1968 & 10 & 0.60 & & 120.90 & & & & & \\
\hline 1968 & 11 & & & 120.90 & & & & & \\
\hline 1968 & 12 & 18.00 & & 138.90 & & & & & \\
\hline
\end{tabular}

\subsection{REDOX Campaigns}

In addition to standard material from single-pass production reactors (Heeb 1993, 1994a, 1994b), REDOX processed small amounts of non-standard fuel from the Hanford Plutonium Recycle Test Reactor (PRTR) as well as off-site fuel from the Shippingport reactor. The inventory of fission products and actinide fuel is higher in the non-standard fuel than in production reactor fuel. Therefore, releases per ton of dissolved uranium for these fuels could be expected to be higher than releases for the production reactor fuel. However, REDOX had specific stack monitoring in place when it processed these non-standard fuels, and apparently no special high activity problems (significant releases) occurred. Such releases would have been noted in the 1965 and 1966 Annual Environmental Monitoring reports (Foster 1966; Honstead 1967).

Except for a first core of aluminum-plutonium alloy fuel, the standard PRTR fuel was zirconium alloy clad uranium and plutonium oxide fuel in 19 rod cluster array (Purcell 1966). The Shippingport 
fuel came from the blanket loading of natural uranium seven rod cluster elements (IAEA 1962). This was high burnup fuel, and the purpose of processing was to obtain americium and curium isotopes (Roberts and Bray 1966a, 1966b). The amount of PRTR and Shippingport fuel processed each month (Roberts 1957) is shown in Table 5.

Table 5. PRTR and Shippingport Processing at REDOX (MTU)

\begin{tabular}{|c|c|c|c|}
\hline Reactor & Year & Month & Tons Uranium \\
\hline PRTR & 1966 & October & 22.3 \\
\hline Shippingport & 1965 & June & 4.3 \\
\hline & & July & 2.2 \\
\hline & & October & 1.8 \\
\hline & & December & 0.6 \\
\hline & 1966 & April & 79.5 \\
\hline & & May & 8.5 \\
\hline & & November & 52.6 \\
\hline & & Total & 149.5 \\
\hline & & &
\end{tabular}




\subsection{Plant (Hot Semi-Works) - Pilot Plant and Strontium Recovery}

The mission of C Plant was to obtain pilot-plant scale data on both REDOX and PUREX separations processes. The building had three heavily shielded process cells, a hot shop for contaminated equipment maintenance, and a ventilation air treatment room (Holsted and Albaugh 1964).

C Plant was started up in November of 1952 (Evans and Tomlinson 1954) for REDOX process pilot runs. Twelve REDOX runs occupied the facility until October 1953 (Evans and Tomlinson 1954). The facility was later reconfigured and used for 22 PUREX simulation runs, ending in run PX-22 in March 1957 (Murray and Sloat 1957). In 1962 the plant was restarted for cesium-strontium fission product recovery (Rockwell 1987). It operated in this mode until it was closed in 1967.

The facility was equipped with deep-bed fiberglass filters on startup. In 1958 a high efficiency particulate air filter was installed to run with the deep-bed fiberglass filters (Rockwell 1987). Each run started with dissolution of less than 1 ton of uranium. Hence, the scale of operation was much smaller than separations plants B, T, REDOX, and PUREX. Releases were smaller in comparison to the full scale plants. Low monthly releases were routinely reported (Paas 1953). Typical releases are shown in Table 6.

Table 6. Typical Releases from C Plant Stack in 1953 (Ci/day)

\begin{tabular}{||l|c|l|l|l|l|c||}
\hline \multicolumn{1}{|c|}{ Month } & $\begin{array}{c}\text { Gross Beta } \\
\text { Monthly } \\
\text { Maximum }\end{array}$ & $\begin{array}{c}\text { Gross Beta } \\
\text { Monthly } \\
\text { Average }\end{array}$ & $\begin{array}{c}\text { Iodine-131 } \\
\text { Monthly } \\
\text { Maximum }\end{array}$ & $\begin{array}{l}\text { Iodine-131 } \\
\text { Monthly } \\
\text { Average }\end{array}$ & $\begin{array}{c}\text { Ruthenium } \\
\text { Monthly } \\
\text { Maximum }\end{array}$ & $\begin{array}{c}\text { Ruthenium } \\
\text { Monthly } \\
\text { Average }\end{array}$ \\
\hline \hline July & 0.16 & $<0.018$ & 0.0057 & blank & 0.16 & blank \\
\hline August & 0.024 & $<0.0066$ & 0.01 & $<0.0004$ & 0.03 & 0.0033 \\
\hline September & 0.043 & $<0.0042$ & 0.0003 & 0.00009 & 0.0099 & 0.0012 \\
\hline $\begin{array}{l}\text { Total for } \\
\text { First Quarter }\end{array}$ & 0.16 & $<0.0084$ & 0.01 & $<0.00058$ & 0.16 & 0.0024 \\
\hline $\begin{array}{l}\text { Total for Last } \\
\text { Quarter }\end{array}$ & 0.088 & $<0.004$ & 0.0026 & $<0.00034$ & 0.055 & $<0.0047$ \\
\hline
\end{tabular}




\subsection{Z Plant - Plutonium Finishing}

Z Plant was dedicated to producing plutonium buttons as well as machined plutonium metal shapes from separations plant plutonium-bearing feed solutions. Potential releases from this facility are plutonium isotopes as well as americium-241 resulting from decay of plutonium-241 (14.5 year half-life). The facility did not process fission products. The four main process buildings are described in Table 7 (Holsted and Albaugh 1964).

Table 7. Z Plant Processing Facilities

\begin{tabular}{||l|l|c||}
\hline Building & \multicolumn{1}{|c|}{ Function } & $\begin{array}{c}\text { Holsted and } \\
\text { Albaugh 1964 } \\
\text { (page \#) }\end{array}$ \\
\hline $231-Z$ & Plutonium machining and metallography. & 2.92 \\
\hline $232-Z$ & Incineration and recovery of dry radioactive wastes. & 2.93 \\
\hline $234-5-Z$ & $\begin{array}{l}\text { Purify and concentrate plutonium-bearing feed solutions } \\
\text { received from separations plants, produce plutonium } \\
\text { metal, fabricate the plutonium metal into weapons } \\
\text { components, recover plutonium-bearing waste streams } \\
\text { for recycling into main process feed solutions. }\end{array}$ & 2.94 \\
\hline $236-Z$ & $\begin{array}{l}\text { Reclaiming plutonium by solvent extraction from liquid } \\
\text { and solid wastes from 234-5 Z, or from off-site sources. }\end{array}$ & 2.96 \\
\hline $242-Z$ & $\begin{array}{l}\text { Recovery of plutonium from low level aqueous waste by } \\
\text { ion exchange and/or solvent extraction. }\end{array}$ & 2.97 \\
\hline
\end{tabular}

The 234-5-Z Building was equipped with a 200-foot vent stack (291-Z Building) exhausting at 183,000 cubic feet per minute. The air stream was continuously sampled for alpha emitting material discharged to the atmosphere (Postma and Schwendiman 1959). Buildings 232-Z, 236-Z, 242-Z were connected to the 291-Z stack (Rockwell 1987). The 231-Z Building had a separate stack exhausting at 16,000 cubic feet per minute (Soldat 1957).

The particulates discharged from the 291-Z stack were plutonium or plutonium compound particles unattached to inert particles. Under normal operating conditions the radioactive particles were less than one micron in diameter. (Postma and Schwendiman 1959, p. 10).

Radioactive discharges from Z Plant were small enough, when compared to the 200 Area separations plant airborne releases, that they were not included in Anderson's 1944-1972 summary of releases (Anderson 1974). However, on April 7, 1962, a criticality accident occurred in the 234-5 Building. This is discussed under the section on criticality accidents. 


\section{0 $\mathrm{U}$ and $\mathrm{UO}_{3}$ Plants - Uranium Recovery}

Two plants were operated to recover uranium left over in the chemical separations plants after the plutonium was extracted from spent fuel rods. The older bismuth phosphate process (B and T Plants, shut down in 1952 and 1956, respectively (Rockwell 1987)) produced by-product uranium waste in the form of sodium uranyl phosphates (soft sludge) and sodium uranyl carbonates (hard sludge). REDOX and PUREX processes produced a uranium nitrate hexahydrate (UNH) by-product solution. U Plant, also called TBP plant because it used tributyl phosphate solvent extraction columns, was designed to convert the $\mathrm{T}$ and $\mathrm{B}$ plant uranium sludges to $\mathrm{UNH}$. $\mathrm{UO}_{3}$ Plant was designed to convert the UNH from U Plant, PUREX, and REDOX to uranium trioxide $\left(\mathrm{UO}_{3}\right)$ orange powder. The $\mathrm{UO}_{3}$ product was sent to offsite fuel cycle facilities for treatment so the uranium could be recycled in reactors.

U Plant, located in the 221 Building, began operations in March 1952 (Rockwell 1987). U Plant shutdown in January 1958 (Rockwell 1987) when it completed processing the last bismuth phosphate waste from T Plant.

The $\mathrm{UO}_{3}$ Plant is located in the 224-U Building, which was built for additional chemical separations processing in 1945 . $T$ and B plants eventually proved capable of providing all the separations services. Therefore, UNH feed stock. solutions were evaporated (calcined) to generate the $\mathrm{UO}_{3}$ product.

$\mathrm{UO}_{3}$ Plant began test runs in January 1952 (Gerber 1993a). By the end of 1953, the product $\mathrm{UO}_{3}$ powder was pure enough to ship directly to the uranium enrichment plants (Gerber 1993a). The plant was placed on standby in September 1972 (Rockwell 1987). It was restarted in March 1984 to process UNH from PUREX N Reactor fuels processing campaigns (Rockwell 1987). The plant was restarted again in April 1993 to convert 200,000 gallons of remaining UNH. Conversion was completed in June 1993 (Gerber 1993a). UO 3 Plant is scheduled for deactivation in 1996 (Gerber 1993a).

$\mathrm{U}$ and $\mathrm{UO}_{3}$ Plants exhausted filtered ventilation air out the 200-foot 291-U stack (Holsted and Albaugh 1964). Anderson (1974) estimates a total of 0.0192 curies of uranium were released for the years 1956 through 1966 . A release of this size spread over 10 years is negligible. 


\section{0 $\mathrm{U}$ and $\mathrm{UO}_{3}$ Plants - Uranium Rècovery}

Two plants were operated to recover uranium left over in the chemical separations plants after the plutonium was extracted from spent fuel rods. The slder bismuth phosphate process (B and T Plants, shut down in 1952 and 1956, respectively (Rockwell 1987)) produced by-product uranium waste in the form of sodium uranyl phosphates (soft sludge) and sodium uranyl carbonates (hard sludge).

REDOX and PUREX processes produced a uranium nitrate hexahydrate (UNH) by-product solution. U Plant, also called TBP plant because it used tributyl phosphate solvent extraction columns, was designed to convert the $\mathrm{T}$ and $\mathrm{B}$ plant uranium sludges to UNH. $\mathrm{UO}_{3}$ Plant was designed to convert the UNH from U Plant, PUREX, and REDOX to uranium trioxide $\left(\mathrm{UO}_{3}\right)$ orange powder. The $\mathrm{UO}_{3}$ product was sent to offsite fuel cycle facilities for treatment so the uranium could be recycled in reactors.

U Plant, located in the 221 Building, began operations in March 1952 (Rockwell 1987). U Plant shutdown in January 1958 (Rockwell 1987) when it completed processing the last bismuth phosphate waste from T Plant.

The $\mathrm{UO}_{3}$ Plant is located in the 224-U Building, which was built for additional chemical separations processing in 1945 . $T$ and B plants eventually proved capable of providing all the separations services. Therefore, UNH feed stock solutions were evaporated (calcined) to generate the $\mathrm{UO}_{3}$ product.

$\mathrm{UO}_{3}$ Plant began test runs in January 1952 (Gerber 1993a). By the end of 1953, the product $\mathrm{UO}_{3}$ powder was pure enough to ship directly to the uranium enrichment plants (Gerber 1993a). The plant was placed on standby in September 1972 (Rockwell 1987). It was restarted in March 1984 to process UNH from PUREX N Reactor fuels processing campaigns (Rockwell 1987). The plant was restarted again in April 1993 to convert 200,000 gallons of remaining UNH. Conversion was completed in June 1993 (Gerber 1993a). UO 3 Plant is scheduled for deactivation in 1996 (Gerber 1993a).

$\mathrm{U}$ and $\mathrm{UO}_{3}$ Plants exhausted filtered ventilation air out the 200-foot 291-U stack (Holsted and Albaugh 1964). Anderson (1974) estimates a total of 0.0192 curies of uranium were released for the years 1956 through 1966. A release of this size spread over 10 years is negligible. 


\subsection{B Plant - Tritium Extraction}

The mission of 108 B Plant was to extract tritium (an isotope of hydrogen with an atomic mass of 3 and a half-life 12.3 years) from irradiated target material. During the production process, tritium leaked from the process lines into the 108 Building ventilation system and was released into the atmosphere.

Initially the tritium target material was lithium fluoride, but the plant was converted to use a lithium-aluminum alloy early in the development process. Target material was irradiated in the Hanford production reactors and sent to the $108 \mathrm{~B}$ facility for extraction of the tritium product. Tritium was created in the reactor neutron flux when lithium-6, a 7.5-percent abundant isotope in natural lithium, absorbed a neutron. The extra neutron broke the compound nucleus into two fragments: tritium and helium-4.

The extraction process removed the aluminum clad and heated the exposed target material in a vacuum furnace, driving off tritium and helium gas. The tritium was then separated from the helium by a palladium metal barrier, which was permeable to all hydrogen isotopes but not to helium isotopes. The product tritium was collected in flasks and sent to Los Alamos in gaseous diatomic form $\mathbf{T}_{2}$.

The process was initially carried out using glass equipment because tritium readily diffuses through metals. The "glass lines," as they were called, were eventually phased out and replaced by stainless steel equipment which is almost impermeable to hydrogen isotopes.

Ventilation hoods were used to minimize worker exposure to tritium. Initially a roof vent with an outlet approximately 75 feet above ground level was used. By the time the process was fully developed, all building and hood air was exhausted to a 300 -foot building vent stack.

A chronology of key 108 B process events is shown in Table 8. The tritium release history is reconstructed from reports that record each month of plant operation (Gydesen 1994). A generic release factor is assumed to apply to all months of operation. The release factor is the ratio of the number of curies released out the vent stack to the number of curies tritium product. This is different from the usual release factor definitions, which derive from the amount of material processed. Information on episudic releases of tritium was added to the routine releases, which were estimated by multiplying the curies of product by the release faitor. There were three release avenues for tritium: from vapor wastes which were "stacked" (released to the atmosphere by ventilation stacks); from solid wastes which were buried beneath the ground; and from liquid wastes which were "cribbed" (poured into cribs or trenches in the ground).

Three references were found which provided cumulative release estimates of tritium. The first of these (Sturges 1951a) states:

A very preliminary estimate of the order of magnitude of this release has been made to cover the period from the start of operations to July 1, 1951. About 9,000 curies have been released through the stack, 20,000 have been buried in our scrap disposal 
Table 8. 108 B Tritium Extraction Process History

\begin{tabular}{||l|l|l||}
\hline \multicolumn{1}{|c|}{ Date } & \multicolumn{1}{|c|}{ Event } & \multicolumn{1}{c|}{ Reference } \\
\hline February 1949 & $\begin{array}{l}\text { First glass line started on } \\
\text { lithium fluoride targets }\end{array}$ & Reed 1952, p. 5 \\
\hline May 1949 & $\begin{array}{l}\text { Last of the lithium } \\
\text { fluoride targets finished }\end{array}$ & Reed 1952, p. 5 \\
\hline August 1949 & $\begin{array}{l}\text { Processing began on } \\
\text { lithium aluminum targets }\end{array}$ & Reed 1952, p. 5 \\
\hline November 1949 & $\begin{array}{l}\text { Four glass lines in } \\
\text { operation }\end{array}$ & Reed 1952, p. 5 \\
\hline May 3, 1951 & $\begin{array}{l}\text { First metal line placed in } \\
\text { operation }\end{array}$ & Chatten 1951 \\
\hline May 3, 1951 & 300-foot stack in operation & Reed 1952, p. 9 \\
\hline August 1954 & Operations shutdown & $\begin{array}{l}\text { Gydesen 1994 for HW- } \\
\text { 89095; company }\end{array}$ \\
\hline
\end{tabular}

pits in the form of unusable furnace pots containing spent alloy, and about 2,500 curies have been disposed of to liquid waste cribs. It will be seen that release to the atmosphere is in the order of one-third the total loss to date. These data have been corrected for decay of product.

The next reference (Sturges 1951b) states:

Incidently, the figures which we included in our memorandum of September 12, 1951 were in error. Units should have been expressed as liters and not as curies. The true curie value in each case would be higher than those stated by a factor of 2.63 .

Furthermore a revaluation of tritium wastes through June 30,1951 has yielded the following new data, which check rather closely with the theoretical estimates of the release:

Release to atmosphere Disposed of to burial Cribbed

Total
16.3 liters

11.5 liters

1.4 liters

29.2 liters. 
The 2.63 correction factor is intended to be the number of curies of tritium per cubic centimeter of diatomic tritium gas. Using a more recent value of 12.33 years for the half-life of tritium (Walker et al. 1977) than Sturges (1951a) did in his calculations, the conversion constant is $2.577 \mathrm{Ci} / \mathrm{cc}$. The product was accounted for in volumes of product gas $T_{2}$ at standard temperature and pressure (STP); i.e., 20 degrees Celsius, one atmosphere.

The third reference (Chatten 1954) states:

The requested data are compiled in Secret Notebook HW-4290-T, Page 141.

The data are calculated and estimated since actual daily assay of the released quantity was not made. The data are the best and the only which are available on the subject. However, from new information which we have gained in this current program, we expect that these data are uncertain, in the aggregate, to the extent of about \pm 20 grams. The plus uncertainty reported here is a result of possible undetected Toepler pump malfunction in the previous program. The minus uncertainty is a result of possible excessive estimates of the quantity of tritium remaining in buried furnace pots.

The data transcribed below are corrected for decay and signify the total quantity of tritium remaining in the indicated location from the cumulative release as of the indicated date.

These data may be corrected for decay to any date in the future, past 3-30-52, by the use of the decay factor 0.99536 per month.

$\begin{array}{ccccc}\text { Date } & \text { Stacked } & \text { Buried } & \text { Cribbed Liquid } & \text { Total(grams) } \\ 3-30-52 & 7.2 & 16.1 & 0.4 & 25.7\end{array}$

Notebook HW-4290-T was destroyed in 1979 (Reed 1951). The three references are, therefore, the only known sources available for determining the release fraction. The first two references (Sturges 1951a, 1951b) are estimates of the decayed product as of the end of June 1951. Effective release factors were calculated for all three of these reference sources by estimating the decay of product amounts reported in the monthly reports to the two end dates: June 30, 1951 and March 30, 1952. These decay estimations were divided into the accumulated stack release given by each of the references quoted above. The gram units in the last reference were converted to cubic centimeters by dividing by $0.00027 \mathrm{~g} / \mathrm{cc}$, the density of $T_{2}$ under STP conditions. The results are shown in Table 9 .

The last column in Table 9 shows the extraction fraction, which is the ratio of the amount of tritium extracted to the arnount contained in the target material. The release amounts were originally given in cubic centimeters. For the calculations in this report, the release amounts were multiplied by $2.577 \mathrm{Ci} / \mathrm{cc}$ to convert the original units to curies. The close agreement in the extraction fraction between the two Sturges references shows that for the early days of the process, the extraction efficiency was about 90 percent. The release fraction difference of 0.032 versus 0.058 arises from a greater release amount being assigned to the stack. The third reference (Chatten 1954) reflects an 
Table 9. 108 B Tritium Release Factor Development

\begin{tabular}{||l|c|c|c|c|c|c|}
\hline \multicolumn{1}{|c|}{ Ref. } & $\begin{array}{c}\text { Stacked } \\
(\mathrm{cc})\end{array}$ & $\begin{array}{c}\text { Buried } \\
(\mathrm{cc})\end{array}$ & $\begin{array}{c}\text { Cribbed } \\
\text { Liq.(cc) }\end{array}$ & $\begin{array}{c}\text { Extracted } \\
(\mathrm{C} i)\end{array}$ & $\begin{array}{c}\text { Release } \\
\text { Fraction }\end{array}$ & $\begin{array}{c}\text { Extract. } \\
\text { Fraction }\end{array}$ \\
\hline $\begin{array}{l}\text { Sturges. } \\
\text { 1951a. }\end{array}$ & 9,000 & 20,000 & 2,500 & 721,594 & 0.032 & 0.899 \\
\hline $\begin{array}{l}\text { Sturges. } \\
\text { 1951b. }\end{array}$ & 16,300 & 11,500 & 1,400 & 721,594 & 0.058 & 0.906 \\
\hline $\begin{array}{l}\text { Chatten. } \\
\text { 1954. }\end{array}$ & 26,667 & 59,630 & 1,481 & $4,401,660$ & .0156 & 0.951 \\
\hline
\end{tabular}

increase in extraction efficiency from 90 percent to 95 percent as the process improved. For the period discussed in the Chatten report, the release fraction had been reduced to 1.56 percent.

The Chatten reference release fraction value of 1.56 percent was selected as the generic release factor. It represents the last and most developed processing of the detailed data in notebook HW-4290-T. The \pm 20 grams out of a total of 25.7 grams uncertainty from the reference permits an estimate of the upper uncertainty factor as $(25.7+20.0) / 25.7=1.778$ and a lower uncertainty factor of $(25.7-20) / 25.7=0.222$ for the releases. If one assumes that any intermediate value is equally likely, the uncertainty would be represented by a uniform distribution with a minimum at 0.222 , mean at 1.00 and maximum of 1.778. The 95-percent confidence level factor would be $1.000 \pm 0.739$ or $(1.739-[1.0-0.739]) /(1.778-0.222)=0.95$, for this distribution.

Table 10 lists the discrete releases which were added to the monthly routine releases.

The annual amount of tritium processed and released is shown in Table 11. The monthly totals are shown in the Appendix along with the monthly 95-percent confidence level minimum and maximum.

The impact of these releases on potential off-site dose was assessed by calculating a monthly dose to a maximum individual at the site boundary using the GENII code (Napier et al. 1988). It was assumed that the release would be in the form of tritium oxide (HTO), which would result in the maximum biological interaction and thus the highest potential dose.

The off-site location with the maximum average air concentration resulting from these chronic releases would have been to the west. The small community of Midway was located immediately outside of the Hanford Site at this location, about $14 \mathrm{~km}$ away. It was assumed the individual lived at this location full time and consumed a diet of local, home-produced vegetables, fruit, meat, and animal products (milk, eggs). 
Table 10. Discrete Tritium Release History from 108 B Plant

\begin{tabular}{||c|c|c|l|l||}
\hline Year & Month & $\begin{array}{c}\text { Release } \\
(\mathrm{cc})\end{array}$ & \multicolumn{1}{|c|}{ Circumstances } & \multicolumn{1}{|c||}{ Reference } \\
\hline 1951 & April & 46 & Out gassing process vessels & Chatten 1951 \\
\hline 1951 & May & 877 & Vented entire lithium-aluminum slug & Chatten 1951 \\
\hline 1953 & Oct & 25 & $\begin{array}{l}\text { Inadvertent release from heating palladium } \\
\text { valve which had adsorbed tritium }\end{array}$ & Sturges 1953 \\
\hline 1953 & Dec & 30 & Gas escaped from pressure sample line & Sturges 1954 \\
\hline 1954 & Jan & 100 & $\begin{array}{l}\text { Inadvertent release from Toepler pump } \\
\text { actuating air line }\end{array}$ & Priode 1954a \\
\hline 1954 & Feb & 4086 & $\begin{array}{l}\text { Tritium leaked from air-contaminated } \\
\text { sample returned from Los Alamos for } \\
\text { purification }\end{array}$ & Priode 1954b \\
\hline 1954 & Mar & 87 & $\begin{array}{l}\text { Inadvertent venting of entrained tritiated } \\
\text { "carbons" }\end{array}$ & Priode 1954c \\
\hline 1954 & July & 57 & 30 cc inadvertent, planned 27 cc & Priode 1954d \\
\hline 1954 & Aug & 40 & 40 cc planned release & Priode 1954e \\
\hline
\end{tabular}

Table 11. Annual Amount of Tritium Processed and Released by 108 B Plant

\begin{tabular}{|c|c|c|}
\hline Year & Tritium Extracted $(\mathrm{Ci})$ & Tritium Released $(\mathrm{Ci})$ \\
\hline 1949 & 42,676 & 683 \\
\hline 1950 & 383,347 & 6,134 \\
\hline 1951 & $1,542,682$ & 27,060 \\
\hline 1952 & $2,483,548$ & 39,737 \\
\hline 1953 & 235,564 & 3,911 \\
\hline 1954 & $6,966,635$ & 122,728 \\
\hline Total & $11,654,452$ & 200,253 \\
\hline
\end{tabular}


The largest releases occurred during the year 1954 (122,700 curies). During 1954, the largest releases occurred in the month of July ( 43,488 curies). The total cumulative release, 1949-1954, was 200,251 curies. The potential maximum individual doses related to these releases is estimated to have been

July 1954

Total 1954

1949-1954
0.3 mrem

0.7 mrem

1.2 mrem. 


\subsection{Area Plutonium Recycle Test Reactor}

The Plutonium Recycle Test Reactor (PRTR) was designed to test plutonium fuel elements in a reactor that could be used for commercial electric power generation. The facility, a vertical pressure tube reactor that used heavy water as the primary loop coolant and neutron moderator, was housed in the 309 Building. The primary coolant loop exchanged the core heat load to a condenser which transferred the heat to the Columbia River.

The PRTR thermal power rating was 70 megawatts (Holsted and Albaugh 1964, p. 3.12). The reactor had a hemispherical steel containment dome extending 75 feet above grade. The containment vessel ventilation exhaust connected to a 150-foot stack (Holsted and Albaugh 1964, p. 3.12).

The reactor began operation (initial critical) in the fall of 1960 (IAEA 1960) and continued until 1969 (Gerber 1993b). On August 21, 1962 a mixed uranium and plutonium oxide fuel rod failed, releasing 1.8 grams of plutonium and 15,000 curies of fission products to the primary coolant system (Purcell 1966). The primary coolant was decontaminated by ion exchange resins after the incident. Releases of xenon-131 and iodine-131 occurred in 1965 due to primary coolant system contamination resulting from tests on predefected fuel rods (Gerber 1993b). On September 29, 1965 a defected fuel rod burst a pressure tube resulting in contamination of both moderator and primary coolant (Gerber 1993b). Heavy water was given an initial cleaning before being shipped offsite for decontamination. Nearly 14 million gallons of water pumped in from the river were contaminated in the cleanup process. Most of it was sent to the 200 Areas for disposal, but some was "disposed of in a natural depression in the ground just east of the 300 Area parking lot" (Gerber 1993b).

Releases to the river were monitored from September 29, 1965 through October 1, 1965 at Richland, Kennewick, and Pasco. Estimates of iodine-131 releases to the Columbia River ranged from 9 curies at Pasco to 20 curies at Richland. The iodine-133 releases were estimated at 55 curies at Richland (AEC 1966). 


\subsection{Area Low Power Test Reactors and Critical Experiment Facilities}

Test reactors and critical experiment facilities were used to test reactor materials, assess new processes, and conduct scientific research. In contrast to the PRTR with its 70-megawatt power rating, these facilities had power levels of a few watts or less. Therefore, they did not contain significant fission or activation product inventories and could not be potential sources of radioactive releases. The possibility of inadvertent power excursions, which might lead to radionuclide releases, existed for these facilities. However, the records reviewed for this report indicate that no such events occurred.

\subsection{Hanford Test Pile (HTP)}

The Hanford Test Pile was operated primarily to test and certify reactor materials to be used in constructing the nine Hanford reactors. It performed reactivity measurements on graphite moderator blocks as well as uranium fuel elements and neutron absorbing materials.

Located in the 305 Building, this reactor was a graphite-moderated, thermal spectrum test reactor with a normal operating power level of 30 watts. The core was an 18-foot cube of graphite blocks. Of 529 circular fuel channels, 292 were fueled with natural uranium fuel. The fuel elements were right circular cylinders approximately 1.5 inches in diameter. The reactor was not cooled (therefore, there was no possibility of coolant water contamination) and never operated far from the "cold, clean, green state." The operating neutron flux was in the $10^{7}$ neutrons per square centimeter per second range. The reactor was controlled by one control rod, a shim rod and two safety rods, one entering the reactor vertically and one horizontally.

The reactor achievec first criticality on February 23, 1944 making it the first operating reactor at the Hanford Site (Nilson 1964). It operated intermittently from 1944 through 1972, and from 1974 through 1975. The reactor was dismantled and buried during 1976 and 1977 (Gerber 1993b).

\subsection{Physical Constants Test Reactor}

Located in 305-B Building, the Physical Constants Test Reactor (PCTR) was designed to perform reactivity measurements on graphite reactor fuel and target materials. It had a flexible core which could be loaded to duplicate proposed graphite reactor lattice configurations. The building also contained a smaller more sensitive graphite-moderated thermal test reactor with a low flux thermal column (Holsted and Albaugh 1964).

\subsection{Plutonium Recycle Critical Facility (PRCF)}

The Plutonium Recycle Critical Facility was designed to support the PRTR mission. It was connected to the PRTR containment vessel by a water canal. It was a heavily-shielded mockup of the 
PRTR core which was used to measure the reactivities of PRTR fuel elements at intervals during the course of their irradiation (Holsted and Albaugh 1964, p. 3.16).

The critical facility consisted of an aluminum tank with fuel elements suspended vertically in the heavy water moderator. The reactor operated at powers up to 100 watts (Holsted and Albaugh 1964 p. 3.16).

The PRCF was operated from 1963 until 1976. In 1988-1989 PRCF hardware and equipment were removed and buried in the 200 Areas (Gerber 1993b).

\subsection{High Temperature Lattice Test Reactor (HTLTR)}

Located in the 318 Building, the High Temperature Lattice Test Reactor was designed to provide neutronics design information on hot graphite reactor lattices in support of DOE's High Temperature Gas-Cooled Reactor program (HTGR). The reactor operated from 1968-1972. In 1973, the irradiated fuel rods were processed at PUREX. No serious wastes or contamination were produced, and the reactor and the control room were removed in the 1978-1982 period (Gerber 1993b).

The reactor was a 10-foot graphite cube with fuel channels. The core could be opened to accommodate a 5-foot test lattice cube. The whole core assembly was thermally insulated and could be operated at $1000^{\circ} \mathrm{C}$ at 2 kilowatts. The coolant was dry nitrogen gas. The fuel rods were made of graphite, uranium oxide graphite, and thoria-dispersed nickel (Gerber 1993b).

\subsection{Training Research Isotopes General Atomics (TRIGA)}

The Training Research Isotopes General Atomics (TRIGA) facility was installed as a neutron source for neutron radiography tests on FFTF fuel elements and jackets (Gerber 1993b).

Located in the 308 Building, TRIGA was placed in a double-containment water tank and operated at 250 kilowatts or less. The 308 Building is scheduled for cleanout and deactivation in the near future (Gerber 1993b). 


\subsection{Criticality Accidents}

Two criticality accidents occurred at Hanford. The first was on November 16, 1951 (Stratton 1989, p. 9) at the P-11 facility. The other was at 234-5-Z on April 7, 1962 (Stratton 1989, p. 10).

The P-11 Facility was a critical mass laboratory which was used for plutonium criticality studies prior to 1952 (Raille 1974). It consisted of two major buildings: the 123 Building (a converted residence) which was used as a control house, and the 120 Building, a single-story metal building 32 feet by 42 feet which contained a critical assembly room, a small chemistry laboratory, a storage and tank room, and a change room.

During an experiment to determine the critical mass of plutonium for various container geometries and solution concentrations, an accidental radionuclide release took place in an aqueous plutonium nitrate solution contained in an unreflected aluminum sphere approximately 20 inches in diameter. The accident occurred during the approach to criticality when the sphere was 93 percent full, as a result of withdrawing a remotely controlled cadmium safety rod without allowing sufficient time between steps. The accident yield was $8 \times 10^{16}$ fissions. This would yield only 0.8 curies of iodine 131. The primary release, therefore, would have been plutonium rather than fission products. A small amount of fuel was forced through the gaskets at the top of the assembly (Stratton 1989, p. 19). No personnel were injured. The building was decontaminated in a few days following the accident, but before cleanup of the test area was completed, a fire occurred and the damaged 120 Building was sealed and abandoned until April 4, 1974 when cleanup and demolition work was initiated. Final site restoration was completed on November 19, 1974 (Raille 1974). It was estimated that no more than $1 \mathrm{gram}$ of plutonium was released to the atmosphere as a result of the fire (Kruesi 1951). The 123 Building was not involved directly in the accident and was raised prior to starting the cleanup of 120 Building (Raille 1974).

The 234-5-Z criticality began on April 7, 1962 and occurred in the plutonium waste recovery facility (Recuplex). Three employees received overexposure to gamma and neutron radiation: 110, 43, and 19 rem (Stratton 1989). There were no fatalities (Investigation Committee 1962).

The following is Stratton's (1989) description of the accident:

This Recuplex system process plant accident involved cleaning up the floor of a solvent extraction hood, a product receiver tank that could overflow into the hood, a temporary line running from the hood floor to a transfer tank (about 18 in. diameter, 69 liter capacity), and the apparent improper operation of valves.

The final triggering mechanism cannot be determined because the testimony of witnesses and operators is not in full agreement with the technical findings of the investigating committee. Although other mechanisms cannot be ruled out, there is a plausible (and simplified) course of events. The receiver tank overflowed into the hood, leaving a solution containing about 45 grams of plutonium per liter on the floor and in the sump: the operator contrary to orders, opened the valve that allowed the solution to be lifted to the transfer tank: and the later addition of aqueous solution (10 to 30 liters at $0.118 \mathrm{~g} /$ liter plutonium) and additional moderation following mixing and/or deareation of the contents of 
the transfer tank led to the excursion. The total excursion yield in the transfer tank was $8 \times 10^{17}$ fissions, with the initial power spike estimated to be no more than $10^{16}$ fissions. Following the spike, the tank was supercritical for 37.5 hours as the power steadily decreased.

Activation of the building criticality alarm resulted in prompt evacuation. At the time (a Saturday morning), 22 people were in the building, only 3 received significant exposure to radiation (110, 43 and 19 rem). The incident itself caused no damage or contamination but did precipitate final shutdown of the plant. The Recuplex operation had been designed as a pilot plant and only later converted to production. A new plant had been authorized before the accident occurred.

Response to the incident was unique. A small, remotely controlled television-equipped robot was used to reconnoiter the building interior, fix precisely the point of the incident (through an attached, highly directional gamma probe), read meters, deposit instrumentation at specified locations, and operate valves on command.

Soldat estimated that " 1,000 curies of noble gases and daughter products were released from the 291-Z stack at about 1100 AM on April 7, followed by an additional total of 200 curies of similar composition over the next two days." He further states that "any possible environmental effects of the cloud were completely undetectable at off-project locations" (Soldat 1962). 


\subsection{Area Fast Flux Test Facility (FFTF)}

The Fast Flux Test Facility is a 400-megawatt, thermal, sodium-cooled reactor plant. It is a low-pressure, high-temperature, fast neutron flux nuclear reactor designed and constructed for irradiation testing of breeder reactor fuels and materials. The 400 Area is a complex array of buildings and equipment arranged around a reactor containment building. The reactor is located in a shielded cell in the center of the containment. Heat is removed from the reactor by liquid sodium circulated through three primary loops (closed recirculating fluid systems consisting of pumps, piping and intermediate heat exchangers) located in the containment cell. Secondary sodium loops transport the reactor heat from the intermediate heat exchangers to forced air-cooled tubes of the dump heat exchangers which exhaust the heat to the atmosphere. Columbia River water is not used to cool the reactor.

The reactor is enclosed in a shielded cell filled with inert nitrogen gas. The stainless steel reactor vessel is 43 feet high and 20 feet in diameter. The reactor core sits in a pool of molten sodium metal which fills the reactor vessel. Inert argon gas covers the top of the sodium pool surface. Compared to the Hanford production reactors, this system is closed to the envirorment.

The core consists of 199 positions into which hexagonal fuel and target assemblies may be loaded. The fuel elements are bundles of tiny stainless steel clad "pins" 0.23 inches in diameter, 217 pins to an assembly. The fuel material is a mixture of plutonium and uranium dioxide located inside the steel cladding of the pin (Walter and Reynolds 1981)

The reactor started operation in 1980 (Walter and Reynolds 1981) and operated until 1993.

Table 12 shows releases from FFTF from 1983-1992 which were reported in the Hanford Annual Environmental Reports. A blank entry means no release reported. The releases are very small as would be expected from the reactor design. 
Table 12. Annual Curie Releases to Air from the Fast Flux Test Reactor

\begin{tabular}{|c|c|c|c|c|c|c|c|}
\hline Year & Tritium & Argoa-41 & Strontium-90 & lodino-131 & Cesium-137 & Plutonium-239,240 & Reference \\
\hline 1983 & & & .000017 & .000007 & & .0000035 & $\begin{array}{l}\text { Price et al. } \\
1984\end{array}$ \\
\hline 1984 & & & .000013 & .0000087 & & .0000025 & $\begin{array}{l}\text { Price ex al. } \\
1985\end{array}$ \\
\hline 1985 & & & .000028 & .0000081 & & .000002 & Price 1986 \\
\hline 1986 & & 24 & .000013 & .000008 & & .000002 & PNL 1987 \\
\hline 1987 & & 36 & .00002 & .000015 & & .000005 & $\begin{array}{l}\text { Jaquish and } \\
\text { Mitchell } \\
1988 \\
\end{array}$ \\
\hline 1988 & & & .000021 & .00001 & & & $\begin{array}{l}\text { Jequish and } \\
\text { Bryce } 1989\end{array}$ \\
\hline 1989 & 1.2 & 22 & & $<.0000054$ & & $<.0000066$ & $\begin{array}{l}\text { Jaquish and } \\
\text { Bryce } 1990\end{array}$ \\
\hline 1990 & 2.9 & 29 & & & .0000068 & & $\begin{array}{l}\text { Woodruff } \\
\text { and Hanf } \\
1991\end{array}$ \\
\hline 1991 & & 27 & & & .0000077 & & $\begin{array}{l}\text { Woodruff } \\
\text { and Hanf } \\
1992\end{array}$ \\
\hline 1992 & & 8.5 & & & .000013 & .0000021 & $\begin{array}{l}\text { Woodruff } \\
\text { and Hanf } \\
1993\end{array}$ \\
\hline
\end{tabular}




\subsection{Conclusions}

This investigation has shown that only very minor releases occurred from facilities other than the Hanford production reactors and the four chemical separations plants. All of the facilities had the potential for radionuclide releases but for different reasons. The reactors all contained neutron fluxes while operating and had the potential for power excursions which could lead to releases. The chemical processing operations handled inventories of radionuclides, which could have been released. The two criticality accidents that occurred had very minor releases to the environment.

The largest release discovered was from tritium extraction operations at the 108 B Plant during the 1949-1954 period. Although the releases themselves were large, the subsequent radiological doses were small.

Table 13 summarizes the conclusions for each of the eight facilities and the criticality accidents.

Table 13. Conclusions

\begin{tabular}{|c|c|}
\hline Facility and/or Activity & Potential or Actual Release \\
\hline $\begin{array}{l}\text { PUREX and REDOX Non } \\
\text { Single-Pass Reprocessing }\end{array}$ & $\begin{array}{l}\text { The processed N, Thoria, Shippingport, and PRTR fuels had } \\
\text { radionuclide concentrations as high or higher than single-pass fuel. } \\
\text { Because releases were constrained by a long cooling time and by } \\
\text { release control equipment, the releases were less than those for } \\
\text { single-pass fuel processing. Annual environmental reports do not } \\
\text { report above normal releases. }\end{array}$ \\
\hline C Plant (Hot Semi-Works) & $\begin{array}{l}\text { Low radionuclide throughput compared to full-scale plants limited } \\
\text { possible releases to fractions of full-scale B,T, REDOX and PUREX } \\
\text { releases. }\end{array}$ \\
\hline Z Plant - Plutonium Finishing & $\begin{array}{l}\text { Potential releases limited to plutonium and americium. Releases of } \\
\text { plutonium smaller than from separations plants. }\end{array}$ \\
\hline $\begin{array}{l}\mathrm{U} \text { and } \mathrm{UO}_{3} \text { Plants - Uranium } \\
\text { Recovery }\end{array}$ & $\begin{array}{l}\text { Potential releases limited to uranium. The } 1956-1966 \text { release is } \\
0.0192 \text { curies. }\end{array}$ \\
\hline 108 B Plant - Tritium Extraction & $\begin{array}{l}\text { Potential release limited to tritium. Estimated life of facility (1949- } \\
1954 \text { ) release } 200,000 \pm 147,000 \text { curies. The dose for this is } \\
\text { estimated to be } 1.2 \text { mrem. Maximum monthly release occurred in } \\
\text { July } 1954 \text { of } 43,500 \pm 32,100 \text { curies. The monthly dose from this } \\
\text { release would be } 0.3 \text { mrem. }\end{array}$ \\
\hline
\end{tabular}


Table 13. (contd)

\begin{tabular}{|c|c|}
\hline Facility and/or Activity & Potential or Actual Release \\
\hline $\begin{array}{l}300 \text { Area Plutonium Recycle } \\
\text { Test Reactor (PRTR) }\end{array}$ & $\begin{array}{l}\text { Potential releases primarily plutonium and fission products. The } 70- \\
\text { megawatt reactor had a containment system and no direct discharge } \\
\text { of cooling water to river. Fuel failure on September } 29,1965 \\
\text { resulted in release of } 20 \text { curies of iodine-131 and } 55 \text { curies of iodine- } \\
133 \text { to the Columbia River at Richland. }\end{array}$ \\
\hline $\begin{array}{l}300 \text { Area Low Power Test } \\
\text { Reactors }\end{array}$ & $\begin{array}{l}\text { Potential releases negligible because of low power, minimal burnup } \\
\text { of fuel. No evidence of excursions or any accidental releases. }\end{array}$ \\
\hline Criticality Accidents & $\begin{array}{l}\text { P-11 accident (November } 16,1951) \text { had potential for plutonium and } \\
\text { fission product release, but excursion limited to } 8 \times 10^{16} \text { fissions } \\
(0.08 \text { curie of iodine-131). Estimated } 1 \text { gram of plutonium released. } \\
\text { Recuplex accident (April } 7,1962) \text { had the potential for plutonium } \\
\text { and fission product release. Excursion lasted } 37.5 \text { hours and yielded } \\
8 \times 10^{17} \text { fissions ( } 0.8 \text { curie of iodino-131). Environmental effects } \\
\text { "undetectable." }\end{array}$ \\
\hline $\begin{array}{l}400 \text { Area Fast Flux Test Facility } \\
\text { (FFTF) }\end{array}$ & $\begin{array}{l}400 \text {-megawatt fast reactor extremely isolated from the environment } \\
\text { by design. Negligible releases to atmosphere. No discharges to the } \\
\text { Columbia River }\end{array}$ \\
\hline
\end{tabular}




\subsection{References}

AEC - Richland Operations Office. 1966. Final Investigative Report of Fuel Element Rupture Test Facility Incident September 29, 1965: Findings and Details; Conclusions and Recommendations. BNWI-918, Parts 1 and 2, Atomic Energy Commission, Richland, Washington

Anderson, J.D. 1974. Emitted and Decayed Values of Radionuclides in Gaseous Wastes Discharged to the Atmosphere from the Separation Facilities Through Calendar Year 1972. ARH-3026, Atlantic Richfield Hanford Company, Richland, Washington.

Chatten, J.C. 1951. P-10 Project: Losses to Atmosphere. HW-21497, General Electric Company, Hanford Works, Richland, Washington.

Chatten, J.C. 1954. Tritium Release. HW-31658. General Electric Company, Hanford Atomic Products Operation, Richland, Washington.

DeNeal, D.L. 1970. Historical Events - Single Pass Reactors and Fuels Fabrication. DUN-6888, Douglas United Nuclear Corporation, Richland, Washington.

Evans, T.F., Tomlinson, R.E. 1954. Hot Semiworks Redox Studies. HW-31767, General Electric Company, Hanford Atomic Products Operation, Richland, Washington.

Foster, R.F. 1966. Evaluation of Radiological Conditions in the Vicinity of Hanford for 1965. BNWL-316. Pacific Northwest Laboratory, Richland, Washington.

Gerber, M.S. 1993a. A Brief History of the PUREX and UO 3 Facilities. WHC-MR-0437, Westinghouse Hanford Company, Richland, Washington.

Gerber, M.S. 1993b. Multiple Missions: The 300 Area in Hanford Site History. WHC-MR-0440, Westinghouse Hanford Company, Richland, Washington.

Gydesen, S.P. 1994. Tritium Extraction Throughput at Hanford, 1949-1954. HW-89095, General Electric Company, Hanford Atomic Products Operations, Richland, Washington.

Heeb, C.M. 1993. Iodine-131 Releases from the Hanford Site, 1944 Through 1947, Vols. 1 \& 2. PNWD-2033 HEDR, Battelle, Pacific Northwest Laboratories, Richland, Washington.

Heeb, C.M. 1994a. Radionuclide Releases to the Atmosphere from Hanford Operations, 1944-1972. PNWD-2222 HEDR, Battelle, Pacific Northwest Laboratories, Richland, Washington.

Heeb, C.M., Bates, D.J. 1994b. Radionuclide Releases to the Columbia River from Hanford Operations, 1944-1971. PNWD-2223 HEDR, Battelle, Pacific Northwest Laboratories, Richland, Washington.

Holsted, P.G., Albaugh, F.W. 1964. Catalog of Hanford Buildings and Facilities 200 Areas. GEH26434 200, General Electric Company, Hanford Atomic Products Operation, Richland, Washington. 
Honstead, J.F. 1967. Evaluation of Radiological Conditions in the Vicinity of Hanford for 1966. BNWL-439. Pacific Northwest Laboratory, Richland, Washington.

IAEA - International Atomic Energy Agency. 1960. Directory of Nuclear Reactors, Vol. III, Research, Test and Experimental Reactors (Supplement to Vol. II). International Atomic Energy Agency, Vienna, Austria.

IAEA - International Atomic Energy Agency. 1962. Directory of Nuclear Reactors, Vol IV, Power Reactors. International Atomic Energy Agency, Vienna, Austria.

Investigation Committee. 1962. Final Report of Accidental Nuclear Excursion Recuplex Operation 234-5 Facility. HW-74723, Atomic Energy Commission, Richland Hanford Operations Office, Richland, Washington.

Jaquish, R.E., Mitchell, P.J. 1988. Environmental Monitoring at Hanford for 1987. PNL-6464, Pacific Northwest Laboratory, Richland, Washington.

Jaquish R.E., Bryce R.W. 1989. Hanford Site Environmental Report for Calendar Year 1988. PNL-6825, Pacific Northwest Laboratory, Richland, Washington.

Jaquish R.E., Bryce R.W. 1990. Hanford Site Environmental Report for Calendar Year 1989. PNL-7346, Pacific Northwest Laboratory, Richland, Washington.

Jungfleisch, F.M. 1992. TRAC Data Files. WHC-92-00001, Westinghouse Hanford Company, Richland, Washington.

Kruesi, F.E. 1951. P-11 Laboratory Fire Investigation, December 4, 1951. HW-22936, General Electric Company, Hanford Atomic Products Operation, Richland, Washington

Murray, J.L., Sloat, R.J. 1957. Hot Semiworks Summary - Run PX-18. HW-49673-RD, General Electric Company, Hanford Atomic Products Operation, Richland, Washington.

Napier, B.A., Peloquin, R.A., Strenge, D.L., Ramsdell, Jr., J.V. 1988. GENII - The Hanford Environmental Radiation Dosimetry Software System. PNL-6584 Vols. 1-3, Pacific Northwest Laboratory, Richland, Washington.

Nilson, R. 1964. Hazards Summary Report Hanford Test Reactor (305 Pile). HW-80600, General Electric Company, Hanford Atomic Products Operation, Richland, Washington.

Paas, H.J. 1953. Radioactive Contamination in the Hanford Environs for the Period July, August, September. HW-30174, General Electric Company, Hanford Atomic Products Operation, Richland, Washington

PNL - Pacific Northwest Laboratory. 1987. Environmental Monitoring at Hanford for 1986.

PNL-6120, Pacific Northwest Laboratory, Richland, Washington. 
Postma, A.K., Schwendiman, L.C. 1959. Radioactive Particles in the 234-5 Building Ventilation Exhaust. HW-61082, General Electric Company, Hanford Atomic Products Operation, Richland, Washington.

Price, K.R. 1986. Environmental Monitoring at Hanford for 1985. PNL-5817, Pacific Northwest Laboratory, Richland, Washington.

Price, K.R., Carlile, J.M.V., Dirkes, R.L., Trevathan, M.S. 1984. Environmental Surveillance at Hanford for CY 1983. PNL-5038, Pacific Northwest Laboratory, Richland, Washington.

Price, K.R., Carlile, J.M.V., Dirkes, R.L., Jaquish, R.E., Trevathan, M.S., Woodruff, R.K. 1985. Environmental Surveillance at Hanford for 1984. PNL-5407, Pacific Northwest Laboratory, Richland, Washington.

Priode, C.A. 1954a. Tritium Released to Atmosphere. HAN-53349, General Electric Company, Hanford Atomic Products Operation, Richland, Washington.

Priode, C.A. 1954b. Tritium Released to Atmosphere. HAN-53978-Del, General Electric Company, Hanford Atomic Products Operation, Richland, Washington.

Priode, C.A. 1954c. Tritium Released to Atmosphere. HAN-54514, General Electric Company, Hanford Atomic Products Operation, Richland, Washington.

Priode, C.A. 1954d. Tritium Released to Atmosphere. HAN-55656-Del, General Electric Company, Hanford Atomic Products Operation, Richland, Washington.

Priode, C.A. 1954e. Tritium Released to Atmosphere. HAN-56028, General Electric Company, Hanford Atomic Products Operation, Richland, Washington.

Purcell, R.H. 1966. Plutonium Recycle Test Reactor Experience. 1962-1966. BNWL-SA-557, Pacific Northwest Laboratory, Richland, Washington.

Raille, M.N. 1974. P-11 Facility Cleanup Summary Report. ARH-ST-106, Atlantic Richfield Hanford Company, Richland, Washington.

Reed, G.G. 1951. Tritium Loss Inventory. HW-4290-T. General Electric Company, Hanford Works, Richland, Washington. (Only copy destroyed as SECRET-RESTRICTED DATA on September 19, 1979.)

Reed, G.G. 1952. History of the P-10 Project as of February 1, 1951. HW-23151-DEL, General Electric Company, Hanford Works, Richland, Washington.

Roberts, F.P., Bray, L.A. 1966a. Recovery of Transplutonium Elements from Redox Waste. BNWL-CC-907, Pacific Northwest Laboratory, Richland, Washington.

Roberts, F.P., Bray, L.A. 1966b. Solvent Extraction of Transplutonium Elements from Redox Shippingport Waste. BNWL-CC-956, Pacific Northwest Laboratory, Richland, Washington. 
Roberts, R.E. 1957. CPD Waste Storage and Experience. HWN-1991, General Electric Company, Hanford Atomic Products Operation, Richland, Washington.

Rockwell. 1987. Rockwell Hanford Operations Historical Timelines of Hanford Operations. RHOHS-ST-10, Vol I, Rockwell Hanford Operations, Richland, Washington.

Shipler, D.B. 1993. Integrated Task Plans for the Hanford Environmental Dose Reconstruction Project, June 1992 through May 1994. PNWD-2187 HEDR, Battelle, Pacific Northwest Laboratories, Richland, Washington.

Soldat, J.K. 1957. Special Filter Samples of Hanford Process Effluent Gases. HW-47941. General Electric Company, Hanford Atomic Products Operation, Richland, Washington.

Soldat, J.K. 1962. Recuplex Incident, April 7, 1962 Emission of Fission Products from the 291-Z Stack. HW-77345, General Electric Company, Hanford Atomic Products Operation, Richland, Washington

Stratton, W.R., revised by Smith, D.R. 1989. A Review of Criticality Accidents. DOE/NCT-04. Lawrence Livermore Laboratory, University of California, Berkeley, California.

Sturgess, D.G. 1951a. Tritium Wastes. HAN-41133. Atomic Energy Commission, Richland Hanford Operations Office, Richland, Washington.

Sturgess, D.G. 1951b. Tritium Wastes. HAN-41693. Atomic Energy Commission, Richland Hanford Operations Office, Richland, Washington.

Sturgess, D.G. 1953. Tritium Released to Atmosphere. HAN-53113. Atomic Energy Commission, Richland Hanford Operations Office, Richland, Washington.

Sturgess, D.G. 1954. Tritium Released to Atmosphere. HAN-53327. Atomic Energy Commission, Richland Hanford Operations Office, Richland, Washington.

Walker, F.W., Kirouac, G.J., Rourke, F.M. 1977. Chart of the Nuclides, Twelfth Edition. General Electric Company, San Jose, California.

Waltar, A.E., Reynolds, A.B. 1981. Fast Breeder Reactors. Pergamon Press, New York, New York.

Woodruff, R.K., Hanf, R.W. 1991. Hanford Site Environmental Report for Calendar Year 1990. PNL-7930, Pacific Northwest Laboratory, Richland, Washington.

Woodruff, R.K., Hanf, R.W. 1992. Hanford Site Environmental Report for Calendar Year 1991. PNL-8148, Pacific Northwest Laboratory, Richland, Washington.

Woodruff, R.K., Hanf, R.W. 1993. Hanford Site Environmental Report for Calendar Year 1992. PNL-8682, Pacific Northwest Laboratory, Richland, Washington. 
Appendix

Monthly Tritium Releases from 108 B 


\section{Appendix}

\section{Monthly Tritium Releases from 108 B}

Table A.1. Monthly Tritium Releases from 108 B

\begin{tabular}{|c|c|c|c|c|c|c|}
\hline Year & Month & $\begin{array}{c}\text { Extracted H-3 } \\
\text { (Ci) }\end{array}$ & $\begin{array}{l}\text { Additional Releases } \\
\text { (Ci) }\end{array}$ & $\begin{array}{c}\text { Total } \\
\text { Released (Ci) }\end{array}$ & $\begin{array}{c}\text { Maximum } \\
\text { Released (Ci) }\end{array}$ & $\begin{array}{c}\text { Minimum } \\
\text { Released (Ci) }\end{array}$ \\
\hline \multirow[t]{12}{*}{1949} & $\operatorname{Tan}$ & 0 & 0 & 0 & 0 & 0 \\
\hline & Feb & 64 & 0 & 1 & 2 & $\overline{0}$ \\
\hline & Mar & 428 & 0 & 7 & 12 & 2 \\
\hline & Apr & 1258 & 0 & 20 & 35 & $\overline{5}$ \\
\hline & May & 723 & 0 & - 12 & 20 & 3 \\
\hline & Jun & 0 & 0 & 0 & 0 & 0 \\
\hline & Jul & 0 & 0 & 0 & 0 & 0 \\
\hline & Aug & 1433 & 0 & 23 & 40 & $\overline{6}$ \\
\hline & Sep & 3182 & 0 & 51 & 89 & 13 \\
\hline & Oet & 7133 & 0 & 114 & 198 & 30 \\
\hline & Nov & 10723 & 0 & 172 & 298 & 45 \\
\hline & Dec & 17732 & 0 & 284 & 493 & $\overline{74}$ \\
\hline \multirow[t]{12}{*}{1950} & Tan & 22757 & 0 & 364 & 633 & 95 \\
\hline & Feb & 23005 & 0 & 368 & 640 & 96 \\
\hline & Mar & 27463 & 0 & 439 & 764 & 115 \\
\hline & Apr & 29025 & 0 & 464 & 808 & 121 \\
\hline & May & 16944 & 0 & 271 & 471 & 71 \\
\hline & Jun & 25757 & 0 & 412 & 717 & 108 \\
\hline & Jul & 42531 & $\overline{0}$ & 680 & 1183 & $\overline{178}$ \\
\hline & Aug & 48278 & 0 & 772 & 1343 & 202 \\
\hline & Sep & 18737 & 0 & 300 & 521 & 78 \\
\hline & Pet & 11161 & 0 & 179 & 311 & 47 \\
\hline & Nov & 14393 & 0 & 230 & 400 & 60 \\
\hline & Dec & 103296 & 0 & 1653 & 2874 & 431 \\
\hline
\end{tabular}

A.1 
Table A.1. (contd)

\begin{tabular}{|c|c|c|c|c|c|c|}
\hline Year & Month & $\begin{array}{c}\text { Extracted H-3 } \\
\text { (Ci) }\end{array}$ & $\begin{array}{l}\text { Additional Releases } \\
\text { (Ci) }\end{array}$ & $\begin{array}{c}\text { Total } \\
\text { Released }(\mathbf{C i})\end{array}$ & $\begin{array}{c}\text { Maximum } \\
\text { Released (Ci) }\end{array}$ & $\begin{array}{c}\text { Minimum } \\
\text { Released (Ci) }\end{array}$ \\
\hline \multirow[t]{12}{*}{1951} & Jan & 15055 & 0 & 241 & 419 & 63 \\
\hline & Feb & 5303 & 0 & 85 & 148 & 22 \\
\hline & Mar & 15057 & $\overline{0}$ & 241 & 419 & 63 \\
\hline & Apr & 19183 & 118 & 425 & 739 & 111 \\
\hline & May & 189804 & 2259 & 5296 & 9210 & 1382 \\
\hline & Jun & 100049 & $\overline{0}$ & 1697 & 2951 & 443 \\
\hline & Pul & 205392 & 0 & 3286 & 5715 & 858 \\
\hline & Aug & 200385 & $\overline{0}$ & 3206 & 5576 & 837 \\
\hline & Sep & 61474 & 0 & 984 & 1710 & 257 \\
\hline & pet & 271366 & 0 & 4342 & 7550 & 1133 \\
\hline & Nov & 139359 & 0 & 2230 & 3878 & 582 \\
\hline & Dec & 314255 & 0 & 5028 & 8744 & 1312 \\
\hline \multirow[t]{12}{*}{1952} & Tan & 774399 & 0 & 12390 & 21547 & 3234 \\
\hline & Feb & 1126404 & 0 & 18022 & 31341 & 4704 \\
\hline & Mar & 582745 & 0 & 9324 & 16214 & 2434 \\
\hline & Aprl & 0 & 0 & 0 & 0 & 0 \\
\hline & May & 0 & 0 & 0 & 0 & 0 \\
\hline & Jun & 0 & 0 & 0 & 0 & 0 \\
\hline & Jul & 0 & 0 & 0 & 0 & 0 \\
\hline & Aug & 0 & 0 & 0 & 0 & 0 \\
\hline & Sep & 0 & 0 & 0 & 0 & 0 \\
\hline & pet & 0 & 0 & 0 & 0 & 0 \\
\hline & Nov & 0 & 0 & 0 & 0 & 0 \\
\hline & Dec & 0 & 0 & 0 & 0 & 0 \\
\hline
\end{tabular}


Table A.1. (contd)

\begin{tabular}{|c|c|c|c|c|c|c|}
\hline Year & Month & $\begin{array}{c}\text { Extracted H-3 } \\
\text { (Ci) }\end{array}$ & $\begin{array}{l}\text { Additional Releases } \\
\text { (Ci) }\end{array}$ & $\begin{array}{c}\text { Total } \\
\text { Released }(\mathrm{Ci})\end{array}$ & $\begin{array}{c}\text { Maximum } \\
\text { Released (Ci) }\end{array}$ & $\begin{array}{c}\text { Minimum } \\
\text { Released }(\mathrm{Ci})\end{array}$ \\
\hline \multirow[t]{12}{*}{1953} & Jan & 235564 & 0 & 3769 & 6554 & 984 \\
\hline & Feb & 0 & 0 & 0 & 0 & 0 \\
\hline & Mar & 0 & 0 & 0 & 0 & 0 \\
\hline & Apr & 0 & 0 & 0 & 0 & 0 \\
\hline & May & 0 & 0 & 0 & 0 & 0 \\
\hline & Jun & 0 & 0 & 0 & 0 & 0 \\
\hline & Jul & 0 & 0 & 0 & 0 & 0 \\
\hline & Aug & 0 & 0 & 0 & 0 & 0 \\
\hline & Sep & 0 & 0 & 0 & 0 & 0 \\
\hline & Det & 0 & 64 & 64 & 112 & 17 \\
\hline & Nov & 0 & 0 & 0 & 0 & 0 \\
\hline & Dec & 0 & 77 & 77 & 134 & 20 \\
\hline \multirow[t]{12}{*}{1954} & Jan & 571459 & 258 & 9401 & 16348 & 2454 \\
\hline & Feb & 310408 & 10530 & 15496 & 26948 & 4044 \\
\hline & Mar & 1149088 & 224 & 18610 & 32362 & 4857 \\
\hline & Apr & 2043680 & 0 & 32699 & 56863 & 8534 \\
\hline & May & 0 & 0 & 0 & 0 & 0 \\
\hline & Pun & 0 & 0 & 0 & 0 & 0 \\
\hline & Jul & 2708840 & 147 & 43488 & 75626 & 11350 \\
\hline & Aug & 183160 & 103 & 3034 & 5275 & 792 \\
\hline & Sep & 0 & 0 & 0 & 0 & 0 \\
\hline & Det & 0 & 0 & 0 & 0 & 0 \\
\hline & Nov & 0 & 0 & 0 & 0 & 0 \\
\hline & Dec & 0 & 0 & 0 & 0 & 0 \\
\hline Total & & 11654452 & 13780 & 200251 & 348237 & 52266 \\
\hline
\end{tabular}




\section{Distribution}

No. of

Copies

Onsite

Technical Steering Pand

D. S. Barth

University of Nevada

4505 Maryland Parkway

Las Vegas, NV 89154

W. A. Bishop

P.O. Box 47651

Olympia, WA 98504-7651

M. L. Blazek

Oregon Department of Energy

625 Marion Street N.E.

Salem, OR 97310

G. G. Caldwell

Tulsa City-County Health Dept.

4616 East 15th Street

Tulsa, OK 74112

S. N. Davis

Dept. of Hydrology and Water Resources

Building 11

University of Arizona

Tucson, AZ 85721

N. J. Germond

224 Iron Mountain Blvd.

Lake Oswego, OR 97034

P. C. Klingeman

Civil Engineering Dept.

Apperson Hall 202

Oregon State University

Corvallis, OR 97331-2302
No. of

Copies

K. J. Kopecky

Fred Hutchinson Cancer Research Center 1124 Columbia Street

Seattle, WA 98104

P. D. McGavran

Dept. of Health and Welfare

450 W. State Street, 4th Floor

Boise, ID 83720-5450

R. L. Morrill

Dept. of Geography, DP-10

University of Washington

Seattle, WA 98195

A. H. Murphy

c/o Max Planck Institute for Meteorology

Bundesstrasse 55

20146 Hamburg

Germany

D. W. Price

Agricultural Economics

Hulbert Hall Room 211

Washington State University

Pullman, WA 99164-6210

M. A. Robkin

Radiological Sciences, SB-75

University of Washington

Seattle, WA 98195

G. S. Roessler

Route 1, Box 139H

Elysian, MN 56028

B. Shleien

2421 Homestead Drive

Silver Springs, MD 20902

Distr.1 
No. of

Copies

A. P. Slickpoo, Sr.

809 Nee Perce Lane

P.O. Box 311

Kamiah, ID 83536

J. E. Till

Route 2 Box 122

Neeses, SC 29107

D. E. Walker, Jr.

P.O. Box 4147

Boulder, CO 80306

Other

2

DOE Office of Scientific and Technical Information

Technical Information Center P.O. Box 62

Oak Ridge, TN 37830

B. Aripa

Environmental Trust

Colville Conferated Tribes

P.O. Box 150

Nespelem, WA 99155

D. Bonga

Kalispel Tribe

P.O. Box 39

Usk, WA 99180

B. G. Brooks, EH-421

Room J-112

U.S. Department of Energy

Germantown, MD 20545

18 K. CharLee

Technical Support and

Public Information

P.O. Box 47651

Olympia, WA 98504-7651
No. of

Copies

J. P. Corley

2213 Torbett

Richland, WA 99352

L. E. Denham

Centers for Disease Control

and Prevention

4770 Buford Highway N.E., F-35

Atlanta, GA 30341-3724

DNR Hanford Projects

Attn: J. R. Wilkinson

Confederated Tribes of the Umatilla Indian Reservation

P.O. Box 638

Pendleton, OR 97801

M. R. Donnelly

Public Health Service

Centers for Disease Control

and Prevention

2201 Sixth Avenue, RX-22

Seattle, WA 98121

D. Ernst

Planning Department

Spokane Tribe

P.O. Box 100

Wellpinit, WA 99040

H. A. Haerer

Golder Associates, Inc.

4104 148th N.E.

Redmond, WA 98052

R. Jim

Confederated Tribes and Bands of the

Yakama Indian Nation

P.O. Box 151

Toppenish, WA 98948

Distr. 2 
No. of

Copies

D. Powaukee

Nez Perce Tribe

P.O. Box 365

Lapwai, ID 83540

M. Queahpama

Vital Statistics

Confederated Tribes of the Warm

Spring Reservation

P.O. Box C

Warm Springs, OR 97761

M. C. Richmond

Department of Civil and

Environmental Engineering

Washington State University

Pullman, WA 99164-2910

L. Seyler

Coeur d'Alene Tribe

Plummer, ID 83851

L. Stembridge

HEAL

1408 West Broadway Avenue

Spokane, WA 99201-1902

M. Squeochs

Confederated Tribes and Bands of the

Yakama Indian Nation

P.O. Box 151

Toppenish, WA 98948

W. L. Templeton

2331 Enterprise Drive

Richland, WA 99352

J. P. Thomas

HHIN Resource Center

1719 Smith Tower

506 Second Avenue

Seattle, WA 98104
No. of

Copies

Onsite

6 DOE Richland Operations Omce

R. F. Brich, TSD

A5-55

Public Reading Room (5)

H2-53

34 Battelle, Pacific Northwest

Laboratories

D. M. Anderson

K8-15

G. L. Black (5)

B1-34

S. D. Cannon

B1-34

D. E. Deonigi

K8-11

P. W. Eslinger

B1-34

W. T. Farris

K3-54

M. D. Freshley

K6-77

R. O. Gilbert

K7-34

W. A. Glass (2)

K3-53

S. P. Gydesen

P8-55

G. L. Harvey

K2-02

C. M. Heeb (5)

K8-34

T. A. Ikenberry

E. B. Liebow

B. A. Napier

K3-54

HARC

K3-54

J. V. Ramsdell

K6-55

D. B. Shipler

S. A. Stage

M. E. Thiede

W. H. Walters

B1-34

K6-55

K6-52

K6-60

Publishing Coordination

K1-06

Records Center (2)

Technical Library (2)

Distr.3 

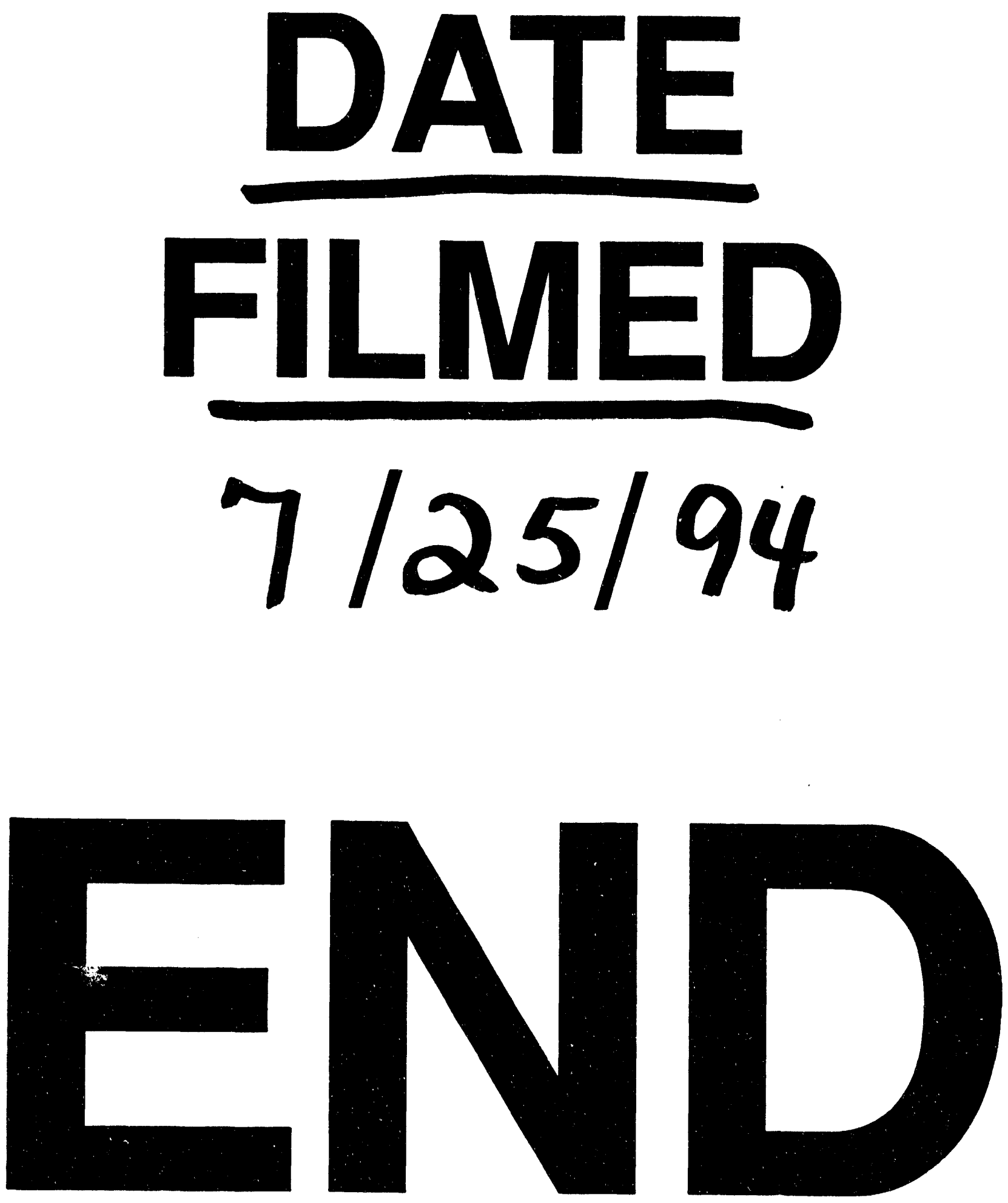


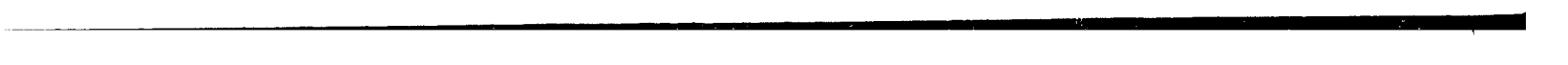

